\title{
Regulatory mechanisms of neutrophil migration from the circulation to the airspace
}

\author{
Wan-Chi Lin ${ }^{1} \cdot$ Michael B. Fessler ${ }^{1}$ (D)
}

Received: 30 September 2020 / Revised: 22 December 2020 / Accepted: 16 January 2021 / Published online: 5 February 2021

(c) This is a U.S. government work and not under copyright protection in the U.S.; foreign copyright protection may apply 2021

\begin{abstract}
The neutrophil, a short-lived effector leukocyte of the innate immune system best known for its proteases and other degradative cargo, has unique, reciprocal physiological interactions with the lung. During health, large numbers of 'marginated' neutrophils reside within the pulmonary vasculature, where they patrol the endothelial surface for pathogens and complete their life cycle. Upon respiratory infection, rapid and sustained recruitment of neutrophils through the endothelial barrier, across the extravascular pulmonary interstitium, and again through the respiratory epithelium into the airspace lumen, is required for pathogen killing. Overexuberant neutrophil trafficking to the lung, however, causes bystander tissue injury and underlies several acute and chronic lung diseases. Due in part to the unique architecture of the lung's capillary network, the neutrophil follows a microanatomic passage into the distal airspace unlike that observed in other end-organs that it infiltrates. Several of the regulatory mechanisms underlying the stepwise recruitment of circulating neutrophils to the infected lung have been defined over the past few decades; however, fundamental questions remain. In this article, we provide an updated review and perspective on emerging roles for the neutrophil in lung biology, on the molecular mechanisms that control the trafficking of neutrophils to the lung, and on past and ongoing efforts to design therapeutics to intervene upon pulmonary neutrophilia in lung disease.
\end{abstract}

Keywords Polymorphonuclear leukocyte $\cdot$ Lung $\cdot$ Pneumonia $\cdot$ Granulocyte $\cdot$ Trafficking $\cdot$ Acute respiratory distress syndrome $\cdot$ Acute lung injury

$\begin{array}{ll}\text { Abbreviations } \\ \text { AT } & \text { Alveolar epithelial type } \\ \text { DARC } & \text { Duffy antigen receptor for chemokines } \\ \text { ELR } & \text { Glu-Leu-Arg } \\ \text { ICAM } & \text { Intercellular adhesion molecule } \\ \text { IL } & \text { Interleukin } \\ \text { LPS } & \text { Lipopolysaccharide } \\ \text { NF } & \text { Nuclear factor } \\ \text { PMN } & \text { Neutrophil } \\ \text { VCAM } & \text { Vascular cell adhesion molecule } \\ \text { VLA } & \text { Very late activation antigen }\end{array}$

Michael B. Fessler

fesslerm@niehs.nih.gov

1 Immunity, Inflammation and Disease Laboratory, National Institute of Environmental Health Sciences, NIH, 111 T.W. Alexander Drive, P.O. Box 12233, MD D2-01, Research Triangle Park, NC 27709, USA

\section{Introduction}

The lung, by virtue of its unique tissue architecture, continual exposure to the environment, and mandate to balance robust antimicrobial host defense with the maintenance of vital gas exchange, has a relationship to the circulating neutrophil (PMN) unlike that of all other organs. Rapid recruitment of PMNs from the bloodstream to the airspace is required for host defense. However, bystander tissue injury from excess or recurrent PMN recruitment contributes to nearly all categories of lung disease. Although the molecular mechanisms of PMN recruitment to the airspace have been studied for decades, foundational discoveries continue to be made. PMN trafficking to the lung differs fundamentally from that in other organs. In part due to the technical challenges of imaging and intervening upon PMN trafficking in the lung in vivo, in several cases, mechanisms of PMN trafficking worked out in other tissues (e.g., cremaster muscle, intestine) have been extrapolated to the lung. In this review, after first discussing intriguing reciprocal homeostatic interactions between the lung and PMN and the unique journey 
that the intravascular PMN follows into the alveolar space during pneumonia, we highlight established and emerging mechanisms for chemokines, the endothelium, and the respiratory epithelium in the regulation of PMN trafficking into the airspace. Last, we close with a perspective on PMNs in lung disease and potential opportunities for therapy.

\section{Homeostatic margination and function of PMNs in healthy lung}

\section{Mechanisms of PMN margination in the lung}

Decades ago, studies of rabbits, sheep, and other animals revealed that non-inflamed lungs during health contain a pool of PMNs that is $\sim 2-3$ times the number of PMNs in the free circulation $[1,2]$. These 'marginated' intravascular PMNs largely localize within alveolar capillaries. A series of landmark studies clarified that PMNs traveling from pulmonary arterioles to venules transit $\sim 8-17$ alveolar walls involving $\sim 40-100$ capillary segments, and that, due to size mismatch, at least half of these capillary segments require PMNs to deform and sometimes to even stop once or more during passage (reviewed in [2]). Likely due to their slower deformability, PMNs have a much longer transit time through the lungs than do erythrocytes [2], accounting, at least in part, for their marked relative concentration within the lung microvasculature. By contrast, studies using intravital labeling have generally reported relatively few extravascular (i.e., interstitial, subepithelial) PMNs in the healthy murine lung, ranging from minimal [3-5] to $\sim 14 \%$ of lung PMNs [6]. One group, however, did observe substantial numbers of extravascular PMNs by two-photon microscopy [7]. Whether this discrepancy reflects technical or environmental (microbiome, caging/bedding) differences is unclear. Virtually no PMNs are found in the alveolar space during health.

Arguing against an important role for molecular adhesion in steady-state PMN margination in the lung, E-, L-, and P-selectins have been shown not to play a role in margination [2, 8-10]. By contrast, PMN CXCR4 may contribute to margination via ligation to pulmonary capillary endothelial CXCL12, although reports differ, with one showing that the CXCR4 antagonist AMD3100 demarginates PMNs from the lungs of mice and non-human primates [11], while another found that it increases pulmonary PMN content in mice [12].

\section{Emerging roles for the lung in the PMN life cycle}

Recent reports that there is a complex community of marginated immune cells in the lung in addition to PMNs (i.e., natural killer $\left[\mathrm{NK}\right.$ ] cells, $\mathrm{CD} 4^{+} \mathrm{T}$ cells, $\mathrm{CD} 8^{+} \mathrm{T}$ cells, invariant $\mathrm{NK} \mathrm{T}$ cells) suggest that the pulmonary microvasculature may provide a niche for transcellular immune communications [4]. The PMN content of the lung microvasculature, in particular, exceeds that of large vessels by $\sim 50$-fold [2], suggesting that, quantitatively, alveolar capillaries are an important stop in the PMN life cycle. Of interest, it was recently reported that aged $\mathrm{CD} 11 \mathrm{~b}{ }^{\text {hi }} \mathrm{L}$-selectin ${ }^{\text {lo }} \mathrm{CXCR} 4{ }^{+} \mathrm{PMNs}$ constitute a large proportion of PMNs in the lung vasculature, that PMNs physically interact with B cells in the lung via CD18, and that this interaction induces PMN apoptosis, committing PMNs to phagocytic removal ('efferocytosis') [13]. This report, taken together with others that aged PMNs may also be preferentially recruited to the lung during inflammation [14], suggests that the lung niche, rather than serving as a simple mechanical sieve for PMNs, may be selective, acting as a major final resting ground for, and homeostatic regulator of PMNs. Of interest, epinephrine induces rapid release of PMNs from the lungs [11]. Conversely, intravenous injection of complement fragments or activated plasma induces rapid and marked retention of PMNs in alveolar capillaries and associated neutropenia $[15,16]$. Collectively, this suggests that the lung serves as an emergency sink and source for PMNs during times of acute systemic stress.

\section{Emerging roles for marginated PMNs in the lung}

In the liver and spleen, intravascular macrophages play an important role in the clearance of pathogens from the bloodstream. By contrast, the lungs in mice and humans are not thought to contain intravascular macrophages. Of interest, a recent report using intravital microscopy indicates that marginated PMNs may serve this surveillance role in the lungs [5]. Yipp and colleagues reported that pulmonary intravascular PMNs crawl short distances along the endothelium in a CD11b-dependent fashion in the steady state, but that these distances increase within minutes of exposure to LPS or bacteria. Moreover, intravascular bacteria were noted to be captured by the pulmonary endothelium through adherence, where they were rapidly targeted by migratory PMNs for phagocytic clearance. Suggesting that PMNs may have a unique affinity for the lung niche, it has been noted that PMNs adhere to pulmonary endothelium in the steady state, unlike dermal endothelium [5]. Beyond CXCL12 [11], the identity of the pulmonary endothelial molecules that specifically address PMNs to the lung in the steady state remain to be identified, as does whether biomechanical signals induced in compressed intracapillary PMNs or in the endothelial cells contacting them poise marginated PMNs and pulmonary microvascular endothelial cells for their cooperative surveillance roles. 


\section{Overview of the microanatomic passage of PMNs into lung during inflammation/ infection}

In the lungs, the conducting airways branch $>20$ times before the terminal alveolar spaces ('alveoli') are reached [17]. In humans, the alveolar surface area has been approximated at $\sim 100 \mathrm{~m}^{2}$ [18]. Alveoli are lined by two types of epithelial cells-squamous alveolar epithelial type 1 (AT1) cells (involved primarily in gas and solute exchange), and cuboidal type 2 (AT2) cells (involved in surfactant synthesis and recycling). Additional cells in the alveolar septal wall during health include endothelial cells, fibroblasts, pericytes, macrophages, and mast cells [18]. Transmission electron microscopy (EM) studies of the alveolar wall have suggested a 'thin' $(\leq 0.2 \mu \mathrm{m})$ side with near apposition of epithelial and endothelial cells overlying a shared basement membrane, and a 'thick' side with interstitial components (e.g., extracellular matrix [ECM], fibroblasts) separating epithelium from endothelium [18].

Reports to date have generally supported a model wherein PMNs emigrating during lung inflammation do not leave the vasculature at the level of high endothelial venules as in other tissues, but primarily at the level of alveolar capillaries [19]. Work by Walker and colleagues using transmission EM and serial section reconstruction suggests that PMNs exit the vasculature paracellularly (i.e., between endothelial cells) at the junction of the thin and thick portions of the alveolar septal wall at a location where interstitial fibroblasts penetrate pre-existing (anatomic) holes in the basement membrane and reach the endothelium [18, 20, 21]. Emigrating PMNs are thought to follow the track of these fibroblasts through the interstitium to pre-existing holes in the subepithelial basement membrane, extensively contacting the fibroblast along the way, and then to enter the alveolus paracellularly at tricellular junctions of two AT1 cells with an AT2 cell [18, 21-23]. During this passage, it is presumed that PMNs use $\beta_{2}$ (CD18)- and $\beta_{1}$-integrins to interact directly with ECM components (i.e., fibronectin, vitronectin, laminin, collagen). That said, the identity and relative importance of specific integrin ligands during different pulmonary exposures, the existence and nature of haptotactic gradients (ECM-bound chemokine gradients) in the lung interstitium, as well as the specific role of interstitial fibroblasts (as well as whether and how they retract to make space for emigrating PMNs) all remain poorly defined.

While paracellular egress of PMNs at the level of the alveolar capillary is generally held as the canonical path for PMNs in the inflamed lung, it is important to note that this has not been firmly established for all pulmonary exposures. Some studies have suggested that a substantial percentage of PMNs may emigrate transcytotically during pneumonia (i.e., directly through the endothelial cytoplasm) [18]. Moreover, PMNs may in some settings emigrate from larger pulmonary vessels rather than capillaries $[18,24]$. Although the course that PMNs follow when they infiltrate the walls of conducting airways during inflammatory airways diseases (e.g., bronchiolitis, bronchitis, bronchiectasis) is less well defined than it is for alveolar diseases (i.e., pneumonia, acute lung injury), it is thought that PMNs in this case egress from the bronchial arterial rather than pulmonary arterial circulation. As the bronchial arteries derive from the systemic circulation (i.e., proximal descending aorta), it is presumed that PMN emigration into the airways may abide by mechanisms similar to those that have been worked out in extrapulmonary tissues such as the cremaster muscle rather than those worked out in the alveolus (discussed below). Moreover, the multicellular architecture of the airway wall, which varies in thickness and complexity along the length of the respiratory tract, almost certainly imposes different constraints on PMNs as they traverse into the airway lumen. The degree to which the specific PMN route into the lung is dependent on the type, deposition site, and dose of the exposure remains largely undefined.

Although most studies of pulmonary neutrophilia have simply quantified PMNs in bronchoalveolar lavage, advanced methods, typically involving pre-mortem intravenous injection of labelling antibodies, have been described that can distinguish intravascular and extravascular (interstitial) PMNs in the lung $[3,4,6]$. As up to $50 \%$ of intravascular PMNs may remain in the lung even after prolonged post-mortem vascular perfusion [3], techniques such as these are invaluable for characterizing the stepwise passage of PMNs from bloodstream to alveolus. Using these methods, Reutershan and colleagues have shown that, in the first hour following LPS inhalation in mice, increased PMNs are sequestered within the pulmonary vasculature, that PMNs then diapedese into the interstitium starting at $\sim 1 \mathrm{~h}$ and increasing to a plateau at $12-24 \mathrm{~h}$, and that transepithelial migration (TEpM) into the alveolar lumen

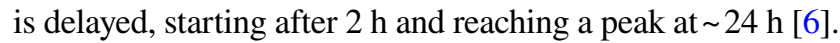
PMNs alter their surface levels of multiple adhesion molecules as they pass through different intrapulmonary tissue compartments (endovascular, interstitial, intra-alveolar), implying that specific adhesive interactions regulate compartmental checkpoints along the journey [25]. 


\section{Cytokine and chemokine induction initiates PMN attraction to the infected lung}

\section{Importance of the IL-17-ELR+CXC chemokine axis}

Cytokine/chemokine induction by sentinel airspace-resident cells (alveolar macrophages, epithelial cells) upon detection of microbes and other pro-inflammatory stimuli is the key initiating event for PMN attraction to the lung (the sequence of events likely differs for PMN recruitment to the lung in response to systemic insults such as endotoxemia but has not been as clearly defined). The transcription factor nuclear factor (NF)- $\mathrm{KB}$ acts as a master regulator for cytokine induction in the lung [26-29]. Important roles have been identified for several pro-inflammatory cytokines (i.e., TNF $\alpha$, IL-1 $\beta, \mathrm{G}-\mathrm{CSF}$ ) in PMN recruitment to the lung through upregulation of endothelial, epithelial, and PMN adhesion molecules, prolongation of PMN survival, and other mechanisms [30, 31]. The potential for complex cytokine interactions is suggested by IL-6-null mice, which have elevated airspace TNF $\alpha$ and increased alveolar neutrophilia following LPS inhalation [30, 31].

A central role for chemokines, in particular, Glu-LeuArg (ELR)+ CXC chemokines (so named for their conserved amino acid sequence) has been identified [31]. These chemokines, which include CXCL1, -2, and -5 in mice and homologues for these plus IL-8 in humans, directly chemoattract PMNs via ligation of the receptor CXCR2 (and CXCR1 in humans). Indeed, LPS-induced alveolar neutrophilia is virtually abolished in CXCR2null mice, suggesting a critical requirement for this axis [32]. Whereas pro-inflammatory cytokines and most chemokines are thought to be generated predominantly by alveolar macrophages, CXCL5 and CXCL15, another ELR + CXC chemokine with an as-yet poorly defined receptor, interestingly are produced by respiratory epithelial cells (AT1, AT2, and Club cells for CXCL5 [33-35]; airway epithelial cells for CXCL15 [36]) and both play important roles in PMN recruitment to the lung [37-39]. Indeed, it has recently been reported that circadian fluctuations in Club cell CXCL5 in response to clock gene-sensitive regulation of the gene by endogenous glucocorticoids underlies circadian variations in the magnitude of alveolar neutrophilia triggered by inhaled LPS in mice [35].

Although isolated AT2 cells release cytokines and chemokines in vitro upon LPS challenge [34], critical upstream roles for hematopoietic cell-derived IL-23 and IL-17 have been identified in vivo in the potentiation of pro-neutrophilic cytokines and chemokines. IL-17 is required for intrapulmonary induction of CXCL2 and G-CSF and for early PMN recruitment to the lung following infection with $K$. pneumoniae [40], a response that is likely driven, at least in part, by epithelial responsiveness to the cytokine via IL-17A and IL-17C receptors [41]. Co-administration of IL-17 and TNF $\alpha$ to the airspace of mice is sufficient to induce ELR+ CXC chemokines and G-CSF in the airspace as well as CXCL5-dependent alveolar neutrophilia [42]. IL-17 can itself be acutely produced by several cell types in the infected lung, including Th17 cells, $\gamma \delta$ T cells, invariant NKT cells, and lymphoid tissue inducer-like cells [43-45]. Yet further upstream, IL-23 has been shown to be a potent activator of IL-17-producing innate cells $[46,47]$. IL-23 is produced in the infected lung by dendritic cells and macrophages [48, 49], and is required for downstream induction of IL-17A and IL-17F, as well as IL-17-induced targets (G-CSF, CXCL1-, -2, -5), pathogen clearance, and survival during Gram-negative bacterial pneumonia [48]. Taken together, these reports identify a transcellular hierarchy of sentinel and messenger cytokines that ultimately induce effector chemokines and cytokines that act directly upon PMNs.

\section{Additional chemoattractants that regulate PMN trafficking into the lung}

The tripeptides $N$-acetyl proline-glycine-proline (PGP) and PGP are generated in the LPS-exposed airspace in a somewhat delayed fashion compared to ELR + CXC chemokines and sustain PMN trafficking to the airspace through direct chemotactic activity upon CXCR $1 / 2[50,51]$. These socalled 'matrikines' are generated by the sequential proteolytic activity of MMP8/9 and prolyl endopeptidase upon collagen in the lung [51], thus relaying local ECM damage in the inflamed lung as a feedforward neutrophilic signal. PGP, which is elevated in the airspace of acute respiratory distress syndrome (ARDS) patients [52] and correlates with disease severity in chronic obstructive pulmonary disease (COPD) [53], is degraded by leukotriene A4 hydrolase (LTA4H) [54, 55], an enzyme better known for its generation of the proinflammatory PMN chemoattractant LTB4.

Eicosanoids, bioactive lipids that are generated from arachidonic acid (AA) released from membrane phospholipid by phospholipase A2, have been shown to play complex, collaborative roles in PMN trafficking to the lungs. PMNderived LTB4 and epithelial-derived hepoxilin A3 (HXA3) have, in particular, been firmly implicated in this regard. LTB4, a lipid that is synthesized by the sequential activities of 5-lipoxygenase (5-LO) and LTA4H upon AA, has long been known as a potent PMN chemoattractant that is upregulated in pro-inflammatory conditions [56] and more recently shown to chemoattract PMNs via the high-affinity BLT1 receptor [57]. PMN-derived LTB4 plays an important role in PMN recruitment to the K. pneumoniae-infected mouse lung [58]. Cytosolic phospholipase A2- $\alpha$-dependent LTB4 generation in PMNs amplifies TEpM in response to 
bacterial infection [59]. Elevated LTB4 has been measured in the lungs of patients with COPD, asthma, and ARDS [60]. Although not all experimental interventions on the LTB4BLT1 pathway have succeeded in attenuating pulmonary neutrophilia in animal models, LTA4H inhibition and select BLT1 antagonists have been shown to have efficacy [60, 61]. HXA3, a 12-LO-derived lipid, is produced by intestinal (T84) and respiratory (A549, H292) epithelial cell monolayers upon Gram-negative bacterial infection, generating an apical-to-basolateral gradient that drives PMN TEpM [62-64]. Respiratory infection of mice with $P$. aeruginosa also induces airspace HXA3 [64]. Interesting differences between LTB4 and HXA3 have been documented. LTB4 but not HXA3 induces PMN degranulation [62] and eosinophil TEpM [65]. It is thought that initial PMN TEpM triggered by epithelial HXA3 may subsequently be amplified by PMNderived LTB4 [66].

\section{Role of extracellular matrix and endothelium in chemokine gradient formation}

Chemokines released by alveolar macrophages and epithelial cells are thought to directionally chemoattract PMNs into the airspace through the formation of concentration gradients through lung tissue and into the vascular lumen. Nearly all chemokines bind to heparin sulfate, chondroitin sulfate, and other tissue glycosaminoglycans via a positively charged C-terminal domain, thereby establishing tissue-bound gradients $[67,68]$. Of interest, it has been shown that matrilysin (i.e., matrix metalloproteinase [MMP]-7) is required to generate a transepithelial gradient of CXCL1 in the lung by ectodomain shedding of syndecan-1, the predominant heparin sulfate proteoglycan on epithelia [69]. The relative potency of chemokines to induce PMN accumulation in the airspace may relate to their association-dissociation kinetics from tissue glycosaminoglycans. Thus, it was reported that, when instilled into the murine airspace, CXCL8 mutants deficient in heparin-binding appeared in plasma at higher concentrations than wild type protein and recruited more PMNs [70]. Similarly, CXCL1 was found to have a higher heparin association-dissociation constant than CXCL2, to appear in plasma more rapidly than CXCL2, and to attract more PMNs to the airspace [70]. Parallel findings were reported in rats [71]. Collectively, these findings imply distinct roles for CXCR2-active chemokines in spatiotemporal control of PMN trafficking to the lung, perhaps explaining why pulmonary chemokines are not fully redundant in vivo [31].

Of interest, CXCL5 was recently reported to antagonize CXCL1- and CXCL2-dependent PMN attraction to the mouse lung during $E$. coli pneumonia by competitive displacement of the latter two chemokines from the scavenger protein duffy antigen receptor for chemokines (DARC) on circulating erythrocytes, thereby increasing plasma levels of CXCL1 and CXCL2, disrupting their gradients, and desensitizing PMN CXCR2 [39]. Further suggesting nonredundancy of chemoattractants, evidence supports a 'hierarchy' of responsiveness at the level of the PMN [72, 73], with bacterial-derived signals having increased priority over host-derived signals, perhaps to ensure accurate terminal targeting of PMNs to sites of infection. Thus, the bacterialmimetic chemoattractant formylated Met-Leu-Phe (fMLP) outcompetes IL- 8 for PMN attraction, even at 1/1000th the concentration, and appears to do so through competitive phosphatase and tensin homolog (PTEN)-mediated suppression of Akt signaling [74, 75].

Ensuring delivery of chemokine gradients to the intravascular PMN, endothelial cells transfer interstitial chemokines from their basolateral to the apical surface. Regulated transcytosis rather than paracellular diffusion is thought to predominate [76]. Prior to overt chemoattraction, endotheliumbound chemokines activate integrins on luminal PMNs, causing firm adhesion and arrest, to be further discussed below. Heparan sulfation on endothelial cells plays an important role in these events, as mice with endothelial heparan sulfate deficiency have reductions in chemokine transcytosis, endothelial display of chemokines, and PMN firm adhesion and migration [77]. Endothelial DARC also mediates basolateral-to-apical transcellular transport of chemokines, supporting PMN emigration [78]. Endothelial DARC was found to transfer CXCL1, enhancing CXCL1-induced $\mathrm{PMN}$ transendothelial migration; thus, reduced PMNs were attracted to the airspaces of DARC-null mice after intratracheal instillation of CXCL8 [79]. Studies using bone marrow chimeras to discriminate endothelial and erythrocyte DARC have suggested that both are required for intact PMN migration into the airspace in response to inhaled LPS, likely due to distinct roles in forming chemokine gradients [80]. By contrast, another group has reported that DARC-null mice have elevated airspace chemokines and PMNs after LPS inhalation and that this phenotype tracks with erythrocyte DARC deficiency [81].

Endothelial cells are themselves also an important source of chemokines for PMN recruitment to tissues, expressing CXCL1 in secretory granules basally [82] and upregulating it in response to cytokines [83, 84]. The finding that endothelial cells null for the common IL-6 family receptor subunit gp130 display increased surface CXCL1, causing inappropriate integrin-dependent PMN arrest and impaired PMN transmigration, indicates that endothelial cell-intrinsic chemokines play key roles in regulated, signal-dependent PMN traffic into tissues [85]. Of interest, PMN-derived chemokines have also been shown to provide feed-forward signals, augmenting further PMN recruitment to the lung [86]. In mouse models of acute lung inflammation, PMN CXCL10 signals in an autocrine fashion through its receptor 
CXCR3 to augment further PMN chemotaxis as well as the PMN oxidative burst [87]. These findings may account for reports of PMN swarming-like behavior in the lung and other organs during inflammation [88]. Finally, a role for endothelial CXCR2 in PMN migration into the LPS-exposed lung, perhaps through induction of endothelial actin stress fibers, has also been suggested by bone marrow chimeric mice [32].

\section{PMN-endothelial interactions and transendothelial migration into the lung}

\section{Sequence of events preceding diapedesis: unique features in the lung}

Work over the past several decades, much of it anchored by intravital microscopy of postcapillary venules in the cremaster muscle and mesentery, has suggested a canonical sequence of events by which PMNs engage and then transit the endothelium as follows: selectin-dependent tethering and rolling, PMN activation, integrin-dependent firm adhesion, intraluminal crawling, and, finally, transmigration [89, 90]. The situation is different, however, in the lung, where PMNs leave the vasculature largely at the level of the alveolar capillary. Here, it has been shown that PMN tethering and rolling likely do not occur, instead of being replaced by mechanical sequestration as cytokine-induced PMN cytoskeletal stiffening due to F-actin polymerization provokes dramatic slowing of PMNs within the narrow-caliber capillaries [19, 91-95]. Selectins have been shown to play no role in PMN recruitment to the lung under certain conditions, such as $S$. pneumoniae infection [10] despite being required for PMN emigration during Pneumococcal peritonitis [96, 97]. Although selectin-mediated tethering per se likely does not occur in alveolar capillaries, antibody blockade studies have nonetheless identified roles for E- and L-selectin, as well as the PMN common selectin counterreceptor, P-selectin glycoprotein ligand-1, in LPS-induced recruitment of PMNs to the lung [98]. L-selectin has also been shown to support PMN recruitment to the $K$. pneumoniae-infected lung, at least in part, through regulation of integrin signaling and integrin-dependent PMN migration [99]. Challenging the paradigm of non-adhesive, mechanical entrapment of PMNs within pulmonary capillaries during inflammation, a recent report identified a role for pulmonary capillary endothelial dipeptidase- 1 in adhesive sequestration of PMNs during endotoxemia [100]. Moreover, another report found that heparanase promotes PMN sequestration in the lung during endotoxemia, likely by thinning the endothelial glycocalyx and exposing underlying adhesion molecules [101].

\section{CD18-dependent and -independent PMN recruitment}

Following the slowing of intravascular PMNs, firm adhesion to the endothelium next initiates the steps leading to diapedesis. The heterodimeric $\beta_{2}$-integrins, CD11a/CD18 $\left(\alpha_{\mathrm{L}} \beta_{2}\right.$; LFA-1) and CD11b/CD18 ( $\alpha_{\mathrm{M}} \beta_{2}$; Mac-1) have been shown to play important roles in PMN trafficking to the lung and other tissues, in particular, mediating firm adhesion of PMNs to endothelium and facilitating PMN chemotaxis across ECM [102]. Of the two $\beta_{2}$-integrins, antibody neutralization studies have supported a more important role for Mac-1 in PMN recruitment to the lung [103]. Landmark reports by Doerschuk and colleagues revealed that pulmonary exposures can be grossly categorized as eliciting alveolar neutrophilia that is CD18 (i.e., $\beta_{2}$-integrin)-dependent vs. CD18-independent, with most exposures favoring but not completely relying upon a single pathway (e.g., LPS-induced neutrophilia is 80\% CD18-dependent) [104-108] (Table 1).

Studies revealing that CD18-dependent stimuli like LPS upregulate the CD18 ligand ICAM-1 on pulmonary capillary endothelium, whereas CD18-independent stimuli such as Pneumococcus do not [109] have suggested that PMN integrin interactions with endothelium are critical. That said, the
Table 1 Inhaled exposures eliciting alveolar neutrophil accumulation through CD18-dependent vs. CD18independent mechanisms

\begin{tabular}{llll}
\hline CD18-dependent stimuli & & CD18-independent stimuli & \\
\hline E. coli LPS & {$[104,105,111]$} & S. pneumoniae & {$[104,105]$} \\
P. aeruginosa & {$[105,107]$} & CXCL1 & {$[111]$} \\
E. coli & {$[279]$} & HCl (ipsilateral lung) & {$[104,280]$} \\
$\mathrm{HCl}$ (contralateral lung) & {$[280]$} & S. aureus ${ }^{* *}$ & {$[279]$} \\
IgG immune complexes & {$[281]$} & Group B Streptococcus & {$[282]$} \\
& & Hyperoxia & {$[283]$} \\
& & IgG immune complexes & {$[281]$} \\
\hline
\end{tabular}

The cited reports measured alveolar neutrophilia in mice, rats, rabbits, or guinea pigs with either CD18 deletion (mice) or antibody neutralization of CD11 or CD18 $\beta_{2}$-integrin components. Partial effects on neutrophilia using the latter method may not decisively distinguish between technical (i.e., dosing) and biological causes

**Partially CD18-dependent 
presence of integrin ligands in the pulmonary interstitium and on respiratory epithelial cells (discussed below) suggests that integrins also regulate important post-endothelial checkpoints during the journey of PMNs to the alveolus. Indeed, the recent finding that mice with the abrogation of high-affinity $\beta_{2}$-integrin activation have increased pulmonary interstitial PMNs during $P$. aeruginosa pneumonia suggests that activated integrins may slow PMN migration into or through the extravascular space in the lung [110]. Moreover, alveolar neutrophilia elicited by CXCL1, as well as the CD18-independent component of LPS-induced neutrophilia, are both mediated by the $\beta_{1}$-integrin CD29, which appears to play a predominant role in the movement of PMNs from interstitium into alveoli (i.e., TEpM) [111]. Of interest, CD29/CD49e (i.e., very late activation antigen [VLA]-5) and CD29/CD49f (VLA-6) heterodimers regulate CD18-independent PMN trafficking to both LPS and CXCL1, whereas heterodimers of CD29 with CD49b (VLA2) and CD49d (VLA-4) are utilized only in trafficking to CXCL1 [111]. VLA-4 also mediates a minor portion of the CD18-independent PMN trafficking to Pneumococcal pneumonia [112]. By contrast, PMN integrin $\beta_{3}$ is reportedly not involved in PMN recruitment to the lungs in Pneumococcal pneumonia [113]. Finally, non-integrin PMN adhesion proteins such as CD47 have also been shown to regulate PMN trafficking to the lung during E. coli pneumonia [114], as further discussed below.

\section{PMN diapedesis}

Although LFA-1 and Mac-1 both bind to ICAM-1 (and other ligands), recent studies have shown that they serve distinct functions in PMN transendothelial migration. In CXCL2treated postcapillary venules imaged by time-lapse intravital microscopy, it was found that LFA-1 mediates initial PMN adhesion and that this is followed by Mac-1 (PMN)-, Vav-1 (PMN)-, and ICAM-1 (endothelial)-dependent intraluminal crawling, often perpendicular to or against the flow of blood, to optimal emigration sites $[115,116]$. Wild type PMNs crawled to intercellular junctions and emigrated paracellularly most $(\sim 86 \%)$ of the time, whereas only $~ 39 \%$ of Mac1-null PMNs emigrated paracellularly, with the remainder emigrating transcellularly, and over a longer period of time [115]. Although PMNs generally appear to favor the paracellular route [23, 117], prolonged stimulation of endothelium with TNF $\alpha$ may increase transcellular migration in a manner dependent upon upregulation of and signaling by ICAM-1 [118]. The existence of transcellular migration in vivo has been supported by studies using serial section transmission EM and scanning EM [119-122]; however, to what extent and under what contexts this occurs in the lung is poorly understood.
Whether transmigrating via the paracellular or transcellular route, PMNs are engaged by concentrated patches of ICAM-1 presented upon microvilli-like projections from the endothelial surface; these patches subsequently further recruit VCAM-1, tetraspanins, and actin, ultimately forming enveloping structures that have been described as 'docking structures' or 'transmigratory cups' [123, 124]. These dome-like, enveloping structures are thought to preserve endothelial barrier integrity during PMN transit [124]. Of interest, intravital two-photon imaging has also revealed that focal collections of intravascular monocytes support PMN transendothelial migration into the lung [7]. Platelets interacting directly with PMNs via P-selectin have also been shown to facilitate PMN recruitment to the LPS-exposed lung $[98,125]$, although the mechanism remains somewhat obscure.

PMNs transiting the paracellular route engage in multiple, sequential molecular interactions with junctional endothelial proteins, including platelet/endothelial cell adhesion molecule (PECAM)-1 (also known as CD31), ICAM-2, junctional adhesion molecules (JAM)-A and -C, and CD99. Molecules that regulate PMN transendothelial migration are catalogued in Table 2. Homophilic interaction between PMN and endothelial PECAM-1 is an early event in junctional engagement by PMNs; PECAM-1 antagonism blocks PMN passage through endothelial junctions, although PECAM1-dependence of PMN transmigration appears to vary by genetic background in mice [126, 127]. Moreover, it is reported that PECAM-1 does not play a role in PMN emigration from pulmonary capillaries in response to either $E$. coli (a CD18-dependent exposure) or S. pneumoniae (a CD18independent exposure) [128]. Endothelial JAM-A serves as a ligand for PMN $\beta_{2}$-integrins, supporting LFA-1-dependent transmigration [129]. JAM-A deletion or blockade reduces LPS-induced airspace neutrophilia, but increases PMNs in lung digests, suggesting impaired trafficking from vasculature to alveolus [130]. JAM-C also mediates PMN transmigration in a Mac-1-dependent manner [131] and has been shown to support alveolar neutrophilia in the LPS inhalation model [132].

PECAM-1, JAM-A, and CD99 not only localize to the junctional surface of endothelial cells, but also to a contiguous, invaginated subjunctional intracellular structure of interconnected tubules and vesicles, the so-called 'lateral border recycling compartment' (LBRC) [133]. Microtubuledependent surface recycling of LBRC molecules is required for PECAM-1 homophilic interactions with PMNs and for transendothelial PMN migration [133, 134], and relies on a transient increase in cytosolic free calcium ion concentration in endothelial cells $[135,136]$. Endothelial transient receptor potential canonical family member six (TRPC6), a cation channel, appears to underlie this event [137]. Homophilic interactions between PMN and endothelial CD99 are 
Table 2 Adhesion molecules that regulate neutrophil transendothelial migration

\begin{tabular}{|c|c|c|c|c|c|}
\hline & \multicolumn{5}{|c|}{ Transendothelial migration } \\
\hline & PMN & endothelium & $\begin{array}{l}\text { PMN-endothelium interac- } \\
\text { tion site }\end{array}$ & Model & Ref \\
\hline CD11a/CD18 (LFA-1) & + & a & Apical, lateral & Primary cell & {$[284,285]$} \\
\hline CD11b/CD18 (Mac-1) & + & a & Apical, lateral & Primary cell & [284-286] \\
\hline $\begin{array}{l}\text { CD11c/CD18 } \\
(\mathrm{p} 150 / 95)\end{array}$ & + & a & ND & Primary cell & [285] \\
\hline CD18-independent integrins & + & a & ND & Primary cell & {$[287,288]$} \\
\hline PECAM-1 (CD31) & - & $+/-*$ & Lateral & $\begin{array}{l}\text { Primary cell, peritonitis, } \\
\text { dermatitis, pneumonia }\end{array}$ & {$[127,128,289]$} \\
\hline $\mathrm{CD} 44$ & + & $+/-$ & ND & $\begin{array}{l}\text { Cremaster muscle, peritoni- } \\
\text { tis, dermatitis }\end{array}$ & {$[155,156]$} \\
\hline CD47 & + & + & Lateral & Primary cell, pneumonia & {$[114,290,291]$} \\
\hline ICAM-1 (CD54) & $?$ & + & Apical, lateral, basal & Primary cell & {$[118,123,284,286,292,293]$} \\
\hline CD55 & + & + & ND & $\begin{array}{l}\text { Cell-free system, primary } \\
\text { cell }\end{array}$ & {$[193,294-298]$} \\
\hline E-selectin (CD62E) & a & $+/-$ & Apical & $\begin{array}{l}\text { Primary cell, peritonitis, } \\
\text { lung inflammation, lung } \\
\text { injury, pneumonia }\end{array}$ & {$[10,90,98,285]$} \\
\hline P-selectin (CD62P) & a & $+/-$ & Apical & $\begin{array}{l}\text { Peritonitis, lung inflamma- } \\
\text { tion, lung injury, pneu- } \\
\text { monia }\end{array}$ & {$[10,16,90,98]$} \\
\hline L-selectin (CD62L) & + & a & Apical & $\begin{array}{l}\text { Primary cell, cremaster } \\
\text { muscle, peritonitis, lung } \\
\text { inflammation, lung injury, } \\
\text { pneumonia }\end{array}$ & {$[16,90,98,99,299]$} \\
\hline CD99 & $+/-$ & + & Lateral & $\begin{array}{l}\text { Primary cell, cremaster } \\
\text { muscle, peritonitis }\end{array}$ & {$[138,139,300]$} \\
\hline ICAM-2 (CD102) & $?$ & + & Apical, lateral & Cremaster muscle, peritonitis & {$[301-303]$} \\
\hline VCAM-1 (CD106) & a & + & Apical & Primary cell & {$[123,304]$} \\
\hline PSGL-1 (CD162) & + & $?$ & Apical & $\begin{array}{l}\text { Intestine, cremaster muscle, } \\
\text { peritonitis, lung inflam- } \\
\text { mation }\end{array}$ & {$[98,305-307]$} \\
\hline JAM-A (CD321) & + & $+/-$ & $\begin{array}{l}\text { Lateral or interaction- inde- } \\
\text { pendent }\end{array}$ & $\begin{array}{l}\text { Primary cell, peritonitis, } \\
\text { cremaster muscle, cardiac } \\
\text { ischemia reperfusion }\end{array}$ & {$[129,308-310]$} \\
\hline JAM-C (CD323) & $\mathrm{a}$ & + & Lateral & $\begin{array}{l}\text { Primary cell, peritonitis, } \\
\text { cremaster muscle }\end{array}$ & {$[131,311]$} \\
\hline ESAM & a & + & Lateral & Cremaster muscle, peritonitis & [312] \\
\hline RAGE & $?$ & + & ND & Cremaster muscle, peritonitis & {$[183,313,314]$} \\
\hline Dipeptidase-1 & a & + & Apical & Systemic inflammation & {$[100]$} \\
\hline Carbohydrate & + & + & Apical, lateral & $\begin{array}{l}\text { Primary cell, cremaster mus- } \\
\text { cle, peritonitis, dermatitis, } \\
\text { hepatitis }\end{array}$ & [315-317] \\
\hline Heparanase & $?$ & + & Interaction- independent & Lung injury & {$[101,318]$} \\
\hline MIF & $?$ & + & Interaction- independent & Lung injury & {$[142,319]$} \\
\hline
\end{tabular}

+ molecule expressed, regulates transmigration, - molecule expressed, does not regulate transmigration, ? molecule expressed, role undefined, $N D$ not determined

*Not involved in transendothelial migration within lung [128]

${ }^{a}$ Denote no or limited available evidence for expression in the indicated cell type

required for the completion of paracellular transmigration $[138,139]$. Finally, PMNs that have passed through the paracellular barrier are thought to migrate short distances along the basal lamina to sites of a low density of collagen IV and laminin that correspond to gaps in pericyte coverage where they exit into the interstitium in a manner involving 
interactions between leukocyte LFA-1 and pericyte ICAM-1 $[140,141]$. It was recently shown that endothelial cellderived macrophage migration inhibitory factor (MIF) signals in a paracrine fashion to its receptor CD74 on pericytes, thereby reducing pericyte contractility and augmenting PMN passage into the lung interstitium and alveolar space in response to LPS inhalation [142].

Vascular endothelial (VE)-cadherin is a type I transmembrane protein exclusively localized in endothelial cells, where it is concentrated at adherens junctions and contributes to endothelial barrier integrity through homophilic cell-cell interactions [143, 144]. VE-cadherin clearance from the site of PMN transmigration by internalization and/or lateral displacement, involving sitespecific phosphorylation, is thought to be required for efficient PMN transmigration [117, 145-147]. VE-cadherin phosphorylation is regulated by its complexation with VEprotein tyrosine phosphatase (PTP), and it has been shown that LPS inhalation triggers dissociation of VE-PTP from VE-cadherin in the lung, thereby promoting PMN recruitment [148]. Moreover, mice engineered to stabilize VEcadherin through a fusion construct with $\alpha$-catenin were found to have a significant reduction in LPS-induced PMN recruitment into the airspace, confirming a role for VEcadherin junctional disassembly in PMN diapedesis from pulmonary vessels [149].

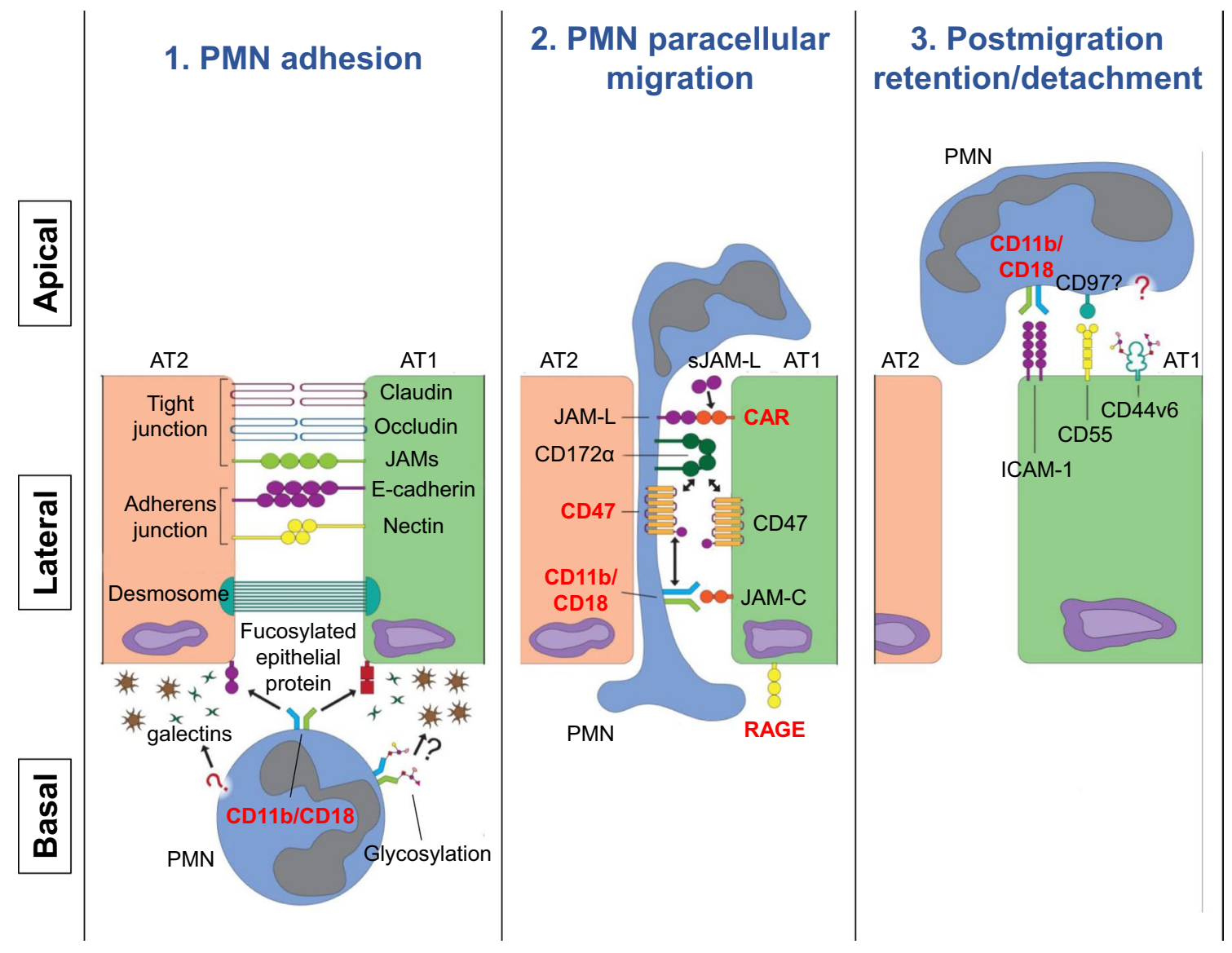

Fig. 1 Transpithelial migration of neutrophils into the airspace. The transepithelial passage of neutrophils (PMNs) from the pulmonary interstitium into the airspace involves the sequential steps of adhesion, paracellular migration, and post-migration adhesion/detachment, as illustrated. Initial adhesive events of PMNs with the basal aspect of epithelial cells may be regulated by PMN CD11b/CD18 interactions with fucosylated proteins and other poorly characterized molecules. Paracellular migration involves serial interactions of PMNs with epithelial junctional proteins, as shown. Finally, apical adhesion is thought to regulate PMN antimicrobial and migratory functions in the airspace and, potentially, to provide positive feedback signals that augment further PMN entry into the paracellular space. The degree to which specific epithelial adhesion proteins are presented by alveolar epithelial type 1 (AT1) vs. AT2 cells is unclear. As discussed in the text, the contribution of some of the adhesion molecules depicted to PMN transepithelial migration in the lung has been largely extrapolated from studies conducted in intestinal systems. Molecules shown in the red font have been confirmed to regulate PMN transepithelial migration in the lungs 


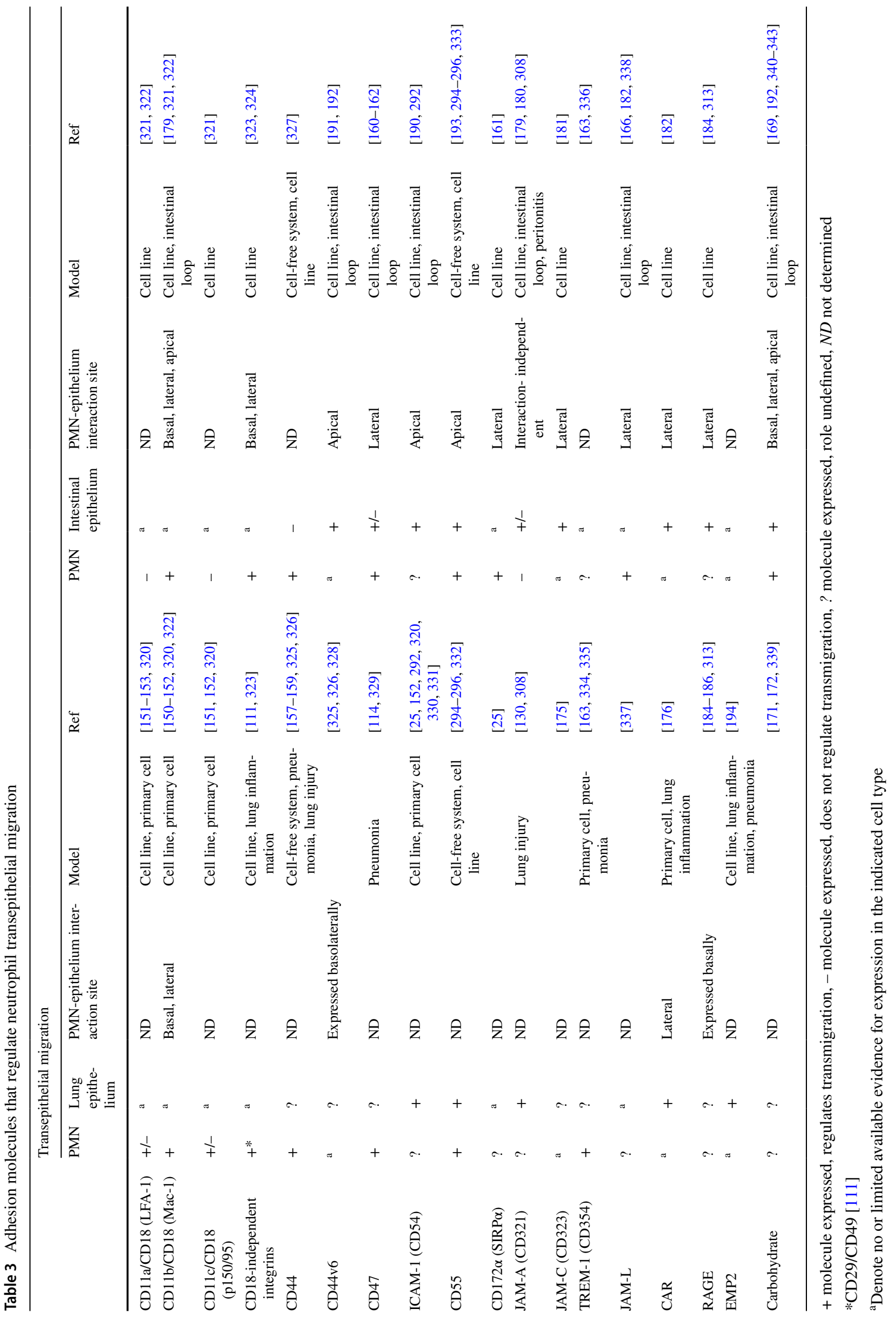




\section{Transepithelial migration (TEpM)}

\section{Neutrophil adhesion molecules and surface receptors that modulate TEpM}

After passage through the interstitium, PMNs arrive at the subepithelial zone, where TEpM commences. This process, comprised of the three sequential steps of epithelial adhesion, paracellular migration, and postmigration retention/ detachment, involves multiple engagements between PMN integrins and their counterpart adhesion molecules on epithelial cells (Fig. 1; Table 3). CD1 1b/CD18 (Mac-1) appears to be the predominant $\beta 2$ integrin regulating PMN transit in most cases of TEpM. Antibody blockade of CD11b or CD18 efficiently inhibits PMN adhesion or transmigration across airway epithelium [150-152]. In a recent study in which PMNs were fractionated from different compartments of lung during inflammation, peak surface expression of CD11b was found on interstitial PMNs, with a decline upon PMN entry into the airway, suggesting a role for CD11b in support of PMN TEpM [25]. In contrast to Mac-1, CD11a/ CD18 (LFA-1) has been shown in a few reports to play a role in PMN adherence to cytokine-stimulated or virus-infected bronchial or nasal airway epithelial cells $[152,153]$. However, this LFA-1-mediated PMN attachment may impact epithelial cell injury more than PMN TEpM [153]. Additionally, as discussed earlier, lung-specific PMN recruitment can also be regulated through CD18-independent mechanisms $[104,108,154]$, and $\beta 1$ integrin CD29 in conjunction with various forms of CD49 in this regard has been recognized as mediating PMN trafficking from the interstitium into alveolus in response to select exposures [111].

Non-integrin adhesion molecules expressed on PMNs such as CD44, CD47, CD172 $\alpha$ (signal regulatory protein, SIRP $\alpha$ ), Junctional Adhesion Molecule-Like protein (JAM-L), as well as surface receptors such as triggering receptor expressed on myeloid cells-1 (TREM-1) have also been identified as key regulators of TEpM. These proteins are discussed individually below and also in Table 3 .

CD44 is a transmembrane glycoprotein that serves as a receptor for multiple ligands including hyaluronan, osteopontin, and MMPs, mediating cellular adhesion and mobility. Interestingly, CD44 was shown to interact with E-selectin [155] and is required for PMNs to adhere or migrate through endothelium [156]. On the other hand, in models of pneumonia and lung injury, the presence of CD44 was shown to impair PMN transit from parenchyma to the bronchoalveolar space, resulting in diminished BAL neutrophilia [157-159]. This suggests that CD44 may be a negative regulator of PMN migration across lung epithelium.

CD47 is a transmembrane immunoglobulin superfamily member expressed on diverse cell types, including PMNs and epithelia. Although perhaps best-known as a self-recognition marker that protects host cells from phagocytic clearance, CD47 has also been shown to participate in PMN trafficking to the lung. Experimental evidence to support this notion showed that CD47 deletion on PMNs significantly reduced their recruitment into pneumonic lung tissues [114]. However, the molecular mechanisms underlying CD47 regulation of TEpM have thus far largely been investigated in the setting of the intestinal epithelium. Preincubation of PMNs with anti-CD47 blocking antibodies was demonstrated to reduce the rate of PMN crossing of colonic epithelium, in part through changes in protein tyrosine phosphorylation, an event downstream of CD47 ligation [160]. In addition, a cis interaction between CD47 and its ligand CD172 $\alpha$ on the plasma membrane of PMNs was found to be critical to CD47-mediated PMN migration across epithelial monolayers [161]. In addition to CD172 $\alpha$, a recent report showed that PMN CD47 could also associate directly with Mac-1 to facilitate TEpM through activation of integrin adhesive function [162].

Despite its status as a cognate ligand for CD47, studies suggest that CD172 $\alpha$ has a role in PMN TEpM somewhat distinct from that of CD47. Unlike the ubiquitous expression of CD47, CD172 $\alpha$ is primarily restricted to myeloid cells and is detectable on nearly all lung-recruited PMNs with a further increase in expression on interstitial and alveolar PMNs [25]. Although it has long been believed that CD172 $\alpha$ on PMNs executes its role in TEpM through simple trans interactions with epithelial CD47, a recent study has challenged this. It was shown in an in vitro model that functional blockade of CD172 $\alpha$ attenuates PMN TEpM, whereas antagonism of epithelial CD47 delays TEpM, suggesting distinct mechanisms [160, 161]. Moreover, a recent study clearly demonstrated that epithelial CD47 is not required for PMN TEpM in vivo; recruitment of PMNs was normal in mice with CD47 exclusively deleted in the intestinal epithelium [162]. Evidence from both studies indicates that CD172 $\alpha$ may have other as yet unclarified functions to control PMN TEpM through mechanism(s) independent of engagement of epithelial CD47.

TREM-1 is another immunoglobulin superfamily member displayed on the surface of PMNs, monocytes, and macrophages. In addition to its originally identified function as an amplifier of pro-inflammatory signaling by pattern recognition receptors, TREM-1 has been shown to be required for PMN migration through respiratory epithelium [163]. Mechanistically, TREM-1 supports NOX2-dependent superoxide production through regulation of the PI3K/AKT signaling pathway, and PMN-derived reactive oxygen species (ROS) support PMN mobility [164]. ROS-supported PMN TEpM has also been demonstrated in both in vitro transmigration assays using human A549 lung epithelial cells and in vivo murine models, where inhibition of ROS significantly 
reduced leukotriene B4-mediated PMN trafficking into the airway [165]. However, direct evidence to link TREM-1 to ROS-mediated PMN TEpM is still lacking.

Although additional PMN adhesion molecules have been shown to regulate PMN TEpM, most of these others have been verified in only intestinal and not pulmonary model systems to date. An example, mentioned above, is JAM-L. Interestingly, during TEpM, in addition to PMN membranebound JAM-L, cleavage of JAM-L from the PMN surface is reported to create a soluble form (sJAM-L) that enables binding to coxsackie adenovirus receptor (CAR) on the tight junction of epithelial cells. This interaction opens up CARdependent epithelial cell-to-cell contact that is believed to facilitate PMN influx across the epithelial barrier to the intestinal lumen [166].

\section{Epithelial adhesion molecules and their regulators that modulate TEpM}

The journey of PMNs from the basolateral side of epithelial cells, ultimately into the airspace lumen, relies upon multiple, sequential specific adhesive interactions of PMN adhesion molecules with cognate ligands that are localized to restricted regions of the epithelial plasma membrane, as displayed in Fig. 1.

\section{PMN adhesion}

PMN-expressed CD11b/CD18 (Mac-1) is thought to regulate all three steps of TEpM (adhesion, paracellular migration, and postmigration retention/detachment) through engagement with a series of ligands localized to restricted regions of the epithelial membrane. However, despite the documentation of $>30$ Mac-1 ligands to date [167, 168], little is known about the identity of the specific Mac-1 ligands expressed on the basolateral aspect of respiratory epithelial cells that impact PMN-epithelial interactions during TEpM. It has been shown that the extracellular domain of $\mathrm{CD} 11 \mathrm{~b}$ has unique lectin-like structures that allow for its association with epithelial cell surface glycan, in addition to engaging epithelial ligands through protein-protein interactions. In studies of the intestine, Zen et al. identified fucoidin as one of a few carbohydrates that can directly bind to Mac-1 and inhibit T84 intestinal epithelial cell adherence to immobilized Mac-1 isolated from human PMNs. Treatment of T84 cells with fucosidase or a proteoglycan biosynthesis inhibitor resulted in a significant reduction of epithelial adhesion, suggesting that fucosylated proteoglycans serve as epithelial ligands that interact with Mac-1 in mediating PMN adhesion [169]. Additionally, epithelial galectins, a class of animal lectin proteins with an affinity for $\beta$-galactose-containing saccharides, have been proposed to play a role in carbohydrate-dependent PMN adhesion [170]. Along these lines, expression of galectins-1, 3, or 9 is induced in the respiratory epithelium during infection/inflammation, correlating with increased PMN infiltration into the lung [171, 172]. Moreover, human PMN Mac-1 is highly decorated with carbohydrate moieties such as sialyl Lewis X [173], which contains a terminal $\beta$-galactose glycan that can be recognized by galectins.

\section{PMN paracellular migration}

Following initial adherence to the epithelial surface, PMNs continue their journey by entering the space between epithelial cells, where they interact with various lateral membrane adhesion molecules to facilitate their apical movement. One such family of laterally expressed adhesion proteins are the JAMs. JAMs belong to the cortical thymocyte marker for Xenopus family, which comprises classical members JAMA, JAM-B, and JAM-C as well as subgroup members such as JAM-4, JAM-L, CAR, CAR-like membrane protein (CLMP), and endothelial cell-selective adhesion molecule (ESAM). Of these, the lung epithelium primarily expresses JAM-A, JAM-C, CAR, and CLMP [174-178]. The tight junctionassociated protein JAM-A has recently been implicated in the regulation of PMN TEpM. Using a murine in vivo vascularized proximal colonic segment model, Flemming et al. showed that intestinal epithelium-targeted deletion of JAM-A enhanced intestinal permeability and simultaneously impaired PMN trafficking across colonic epithelium [179]. Intriguingly, the mechanism by which JAM-A mediates PMN TEpM may be $\beta 2$ integrin-independent, as JAM-A is a ligand for LFA-1 [129] but not Mac-1, and there is no clear evidence, to the authors' knowledge, that LFA-1 plays a role in PMN TEpM. More recently, Luissint et al. provided evidence that the reduction of PMN transmigration into the colonic lumen in JAM-A-deficient mice might be due to increased gut permeability that impairs macrophage-dependent PMN recruitment [180]. In an acute lung injury model, JAM-A deficient mice also had diminished PMN recruitment into the airspace with increased interstitial PMN accumulation, suggesting a similar role for JAM-A in mediating PMN transmigration across the epithelium in the lungs as that observed in the intestines [130]. In contrast to JAM-A, JAM-C serves as a component of desmosomes at the lateral side of intestinal epithelial cells, where it regulates PMN TEpM through direct binding to PMN Mac-1 [181]. JAM-C has also been shown to regulate monocyte migration across influenza A virus-infected murine primary alveolar epithelial cells (AECs) [175]. Although not yet formally demonstrated to our knowledge, a similar role for JAM-C in PMN TEpM appears likely. As discussed above, CAR, another tight junction epithelial protein, enables PMN TEpM via interaction with JAM-L expressed on PMNs or SJAM-L. 
CAR-dependent PMN TEpM has been documented in both the intestinal and respiratory systems [176, 182].

The receptor for advanced glycation end products (RAGE), a member of the immunoglobulin superfamily that can bind to Mac-1 [183] among other ligands, may also have a role in PMN TEpM in the lungs. In addition to its role as a pattern recognition receptor in the innate immune response, RAGE has been reported to be a ligand for $\beta 2$ integrins, suggesting potential for direct roles in leukocyte recruitment. Under inflammatory conditions, RAGE is upregulated and localizes to the lateral membrane of intestinal epithelial cells near apical adherence junctions. Functional blockade of RAGE inhibits T84 cell adhesion to Mac-1 and prevents PMNs from crossing T84 epithelial monolayers, suggesting RAGE may serve as an epithelial adhesive ligand for PMN Mac-1 during TEpM [184]. Given the cellular location of RAGE at the lateral aspect of epithelial cells, but close to apical junctions, its function is likely more similar to JAM-C and CAR (in regulating PMN paracellular migration) than to that of proteins that support initial PMN adhesion. However, in the lungs, RAGE expression is prominent in alveolar epithelial type 1 (AT1) cells and has been reported to predominate on basal membranes of AT1 cells [185, 186]. AntiRAGE antibody treatment or deletion of RAGE attenuates PMN recruitment and accumulation in the lung parenchyma and airspace [187-189]. Further studies are needed to clarify to what extent this arises from defective PMN TEpM, as RAGE possesses additional immunoregulatory functions.

\section{Postmigration retention/detachment}

After migrating paracellularly, PMNs emerge at the apical epithelial surface. Their subsequent retention or detachment is determined by multiple adhesive interactions. ICAM-1, a member of the immunoglobulin superfamily, is one of the best-characterized ligands for $\beta 2$ integrins. Proinflammatory stimuli upregulate ICAM-1 on the surface of tracheal, bronchial, and alveolar epithelial cells, where the expression appears to be restricted to the apical surface. Of interest, apical ICAM-1 has been shown not only to promote PMN adhesion and locomotion on the apical surface of epithelium, thereby supporting PMN antimicrobial function, but also to augment PMN TEpM [190]. The latter occurs through myosin light-chain kinase-dependent changes in epithelial permeability to PMN traffic, thus suggesting a feedforward mechanism for PMN TEpM.

An additional epithelial adhesion molecule that regulates PMN detachment from the apical side of epithelium is CD44v6, an alternative splice isoform of CD44 [191]. Although the details of how CD44v6 is regulated to engage with PMNs are unclear, it has been reported that post-translational glycosylation of CD44v6 with sialyl Lewis A is required for its interaction with PMNs [192]. In addition, the decay-accelerating factor, CD55, is another anti-adhesive protein on the apical membrane of epithelium [193]. However, its counter-ligand on PMNs remains unidentified, to our knowledge.

\section{A new epithelial regulator of PMN TEpM in the lung}

In addition to the relative paucity of studies to date that have demonstrated roles for TEpM-regulatory epithelial adhesion molecules specifically in the lung, the question has remained of whether the expression of different adhesion molecules is coordinated in respiratory epithelium. Recently, our laboratory identified epithelial membrane protein 2 (EMP2), a tetraspan membrane protein highly expressed by AT1 cells, as a master regulator of PMN TEpM into the airspace [194]. Prior to our report, EMP2 had been identified as a lipid raft-resident protein that supports the recruitment of select integrins ( $\alpha 6 \beta 1, \alpha v \beta 3)$, adhesion molecules (ICAM1 ), and signaling proteins to lipid rafts, and that downregulates caveolins [195-197]. Despite its high expression in the lung, where it is expressed at the protein level in AT1 cells, but not AT2 cells nor alveolar macrophages [198], no function had been established for EMP2 in lung biology. We found that EMP2-null mice have reduced recruitment of PMNs into the airspace in response to inhalation of LPS and reduced neutrophilic lung injury during bacterial pneumonia. In the case of LPS, an excess of interstitial PMNs was found in EMP2-null mice, suggesting defective TEpM. AT1 cells from $E m p 2^{-/-}$mice had dysregulated surface display of multiple adhesion molecules (CD47, ICAM-1, $\beta 3$ integrin). EMP2-silenced epithelial cell cultures recapitulated this altered display and were defective in supporting transmigration of PMNs. The defective adhesion protein display and TEpM of EMP2-deficient epithelia were both rescued by silencing of caveolin-2. Taken together, this suggests that EMP2 coordinates the proper display of multiple adhesion molecules that support PMN TEpM through repression of caveolin proteins in trans. Given the high expression of EMP2 in the lung and its potential tractability to inhaled therapeutics, these findings suggest exciting potential for EMP2 as a target in neutrophilic lung disease.

\section{Considerations for intervening upon PMNs in acute and chronic lung disease}

The canonical, and, presumably, the evolutionary function of PMN recruitment to the lung is pathogen killing during an acute respiratory infection. In this context, PMN-derived proteases, oxidants, antimicrobial peptides, and extracellular traps contribute to the clearance of bacteria from the alveolus. Of interest, although cell depletion studies have confirmed a critical role for PMNs in host survival during 
bacterial pneumonia [199], increased PMN recruitment to the lungs during pneumonia can in some instances be harmful. Thus, mice null for the transcription factor $\mathrm{p} 53$, the lipid transporter ABCG1, the cytokine IL-10, or the phosphatase PTEN all have increased pulmonary neutrophilia during Gram-negative bacterial pneumonia; despite enhanced bacterial clearance from the lung, these animals all exhibit increased mortality likely due to exacerbated lung injury [200-203]. Conversely, mice with myeloid deficiency of PTEN have reduced PMN recruitment to the lung during pneumococcal pneumonia with unaltered pathogen burden but improved survival [204]. Recently, our group reported that mice null for EMP2 have improved survival during bacterial pneumonia in the setting of a reduced transepithelial influx of PMNs into the airspace lumen; interestingly, at high bacterial inocula, this airspace PMN deficit was associated with improved pathogen clearance [194]. Others have also shown that PMNs may compromise pulmonary host defense in other contexts, via enhancement of Pseudomonas biofilm generation [205] and promotion of bacterial colonization in the lung [206].

Collectively, these studies indicate that PMN recruitment to the lungs during pneumonia may be dissociable from both pathogen clearance and host survival. This suggests that there may be an optimal magnitude or kinetics of pulmonary neutrophilia during infection and/or that qualitative features of pulmonary neutrophils, such as their intrapulmonary localization, local programming, function, or interactions with other cell types may be as important as PMN number. Further suggesting context-dependent roles for the PMN in lung infection, both beneficial and deleterious functions have been reported for PMNs during influenza pneumonia [207]. The degree and timing of neutrophilia, type of influenza virus, and age of the host may be key determinants $[86,208]$. Emerging reports that PMN extracellular traps may drive pathogenesis in COVID-19 pneumonia also suggest mixed roles for the PMN in pulmonary defense against SARS-CoV-2 [209].

Although numerous publications have shown that PMNs can injure the lung in both acute and chronic settings, further complicating our expectations for this cell type are reports that PMNs also mediate lung repair. Thus, PMNs activate $\beta$-catenin-dependent epithelial repair in the LPS-challenged lung during their transit across the epithelium [210] and also promote re-epithelialization after acid-induced lung injury [211]. PMN-derived MMP9 plays an important role in repair following ventilator-induced lung injury, likely through the processing of extracellular matrix [212]. PMNs also participate in transcellular biosynthetic circuits that generate specialized pro-resolving lipid mediators [213] and suppress lung inflammation via transfer of miR-223 to pulmonary epithelial cells [214]. Apoptotic PMNs sequester chemokines during resolution of inflammation [215] and also program efferocytic macrophages to resolve lung inflammation [216]. Indeed, PMN depletion reportedly exacerbates lung inflammation and injury induced by influenza virus [217]. Taken together, these reports suggest that PMNs are not monotonic with respect to either pulmonary host defense or lung injury, and that selective or even context-dependent strategies may thus be necessary to intervene upon them in lung disease. Layered on top of this consideration are reports that multiple PMN functions, including chemotaxis, respiratory burst, degranulation, and phagocytosis are dysregulated in chronic lung diseases such as COPD and bronchiectasis [218, 219].

\section{Therapeutic avenues for controlling PMN traffic to the lungs: past and ongoing trials}

Multiple therapeutic strategies for modulation of PMN traffic to the lungs have been tested to date, including inhibitors of adhesion molecules, chemokines, and intracellular signaling molecules, as discussed in the sections that follow. It is important to note that few of these strategies have been lung-selective or even PMN-selective and that inhibition of PMN trafficking to the lungs, as with other tissues, may carry untoward effects on host defense. In addition, in many cases, the full collateral impact of these strategies on the antimicrobial functions of PMNs remains to be defined.

\section{Targeting adhesion molecules needed for PMN entry into lungs}

Given the crucial role of adhesion molecules in the regulation of PMN migration to inflamed tissues, inhibition of these molecules holds promise as a strategy for curtailing the exacerbated inflammation in neutrophilic acute/chronic lung diseases. As discussed above, adhesion molecules that facilitate PMN recruitment to the lungs/airways include those on (1) PMNs-L-selectin, $\beta 2$ integrin, $\alpha 4$ integrin; (2) endothelium-E-selectin, P-selectin, ICAM-1, VCAM1, PECAM-1; (3) epithelium-CD47, ICAM-1, $\beta 3$ integrin; and (4) platelets-P-selectin. Deficiency of these molecules in humans or mice has been reported to attenuate PMN migration, supporting the potential of these molecules as drug targets. Select adhesion molecules have been tested as therapeutic targets to date, with mixed results.

The therapeutic potential of an inhaled pan-selectin antagonist, TBC-1269 (Bimosiamose), was investigated in patients with COPD and in an ozone-induced human airway inflammation model. The individuals receiving the treatment showed slightly reduced airway inflammation (sputum IL-8, MMP9). However, this marginal effect was mainly attributed to a reduction in recruited macrophages, not PMNs [220, 221]. Additional selectin antagonists, including the pan-selectin inhibitor GMI-1710 (Rivipansel) as well as a 
humanized monoclonal antibody against P-selectin SelG1 (Crizanlizumab) and E-selectin-specific inhibitors GMI1271 (Uproleselan) and GMI-1687 have been/are being examined in trials for diseases such as sickle cell disease or hematological malignancies (multiple myeloma, acute myeloid leukemia). Whether they can be applied to respiratory diseases needs further investigation.

Although integrin and ICAM-1 antagonists have mostly been investigated in non-respiratory diseases, these agents may have the potential for repurposing for lung inflammation. Efalizumab (Raptiva) and Natalizumab (Tysabri) are humanized monoclonal antibodies against $\beta 2$ and $\alpha 4$ integrins on PMNs. Unfortunately, clinical trials of these two drugs in psoriasis, multiple sclerosis, or Crohn's disease were terminated early due to reports of progressive multifocal leukoencephalopathy [222]. In contrast to the antiintegrin agents, ICAM-1-targeting biologics including the monoclonal antibody BI-505 (Bersanlimab) and antisense oligodeoxynucleotide ISIS 2302 (Alicaforsen) appear to have an improved safety profile. Nonetheless, Bersanlimab was found to be ineffective in multiple myeloma [223], and alicaforsen did not deliver a positive result in Crohn's disease [224, 225]. A modified version of alicaforsen formulated for topical application that was thought promising for ulcerative colitis also failed to meet the primary endpoint in recent trials [226-228]. A new line of a human antibody, MSH-TP15, was recently developed to target ICAM-1 [229]; further confirmation of its safety and efficacy in clinical practice is awaited.

While, to date, most anti-adhesion molecule strategies have been designed with the PMN and/or endothelium in mind, strategies targeting the pulmonary epithelium (i.e., TEpM) carry promise for a lung-selective effect. Along these lines, as discussed above, our laboratory recently reported that EMP2, a protein highly expressed by the alveolar epithelium, regulates epithelial surface display of multiple adhesion proteins. Downregulation of EMP2 reduced PMN TEpM into the inflamed airspace without an untoward effect on antibacterial host defense [194]. Our preliminary study also showed that airway delivery of an anti-EMP2 biologic reduced airspace neutrophilia induced by LPS in wild-type mice. This finding suggests the exciting potential for lung-directed (i.e., inhaled) anti-EMP2 therapeutics in neutrophilic lung disease.

\section{Targeting chemoattractant receptors needed for PMN entry into lungs}

An oral CXCR2 antagonist, AZD-8309, developed for the treatment of COPD was tested in healthy individuals challenged with inhaled LPS. Despite an initial positive result showing a $\sim 80 \%$ reduction in sputum PMNs compared to placebo as well as decreased PMN elastase activity [230], the development of this drug was reportedly discontinued in 2007.

AZD-5069 is a selective CXCR2 antagonist that was shown to be well tolerated and without overt increased risk for infection. Its efficacy was investigated in trials for moderate-to-severe COPD, bronchiectasis, and severe asthma. A significant decrease in PMN counts in sputum or lung tissues was observed; however, the diminished neutrophilia did not translate into improved disease outcomes [231-234].

Another selective and reversible CXCR2 antagonist, GSK1325756 (Danirixin), has also been tested in patients with COPD. However, no clear benefit was observed with treatment and an increase in pneumonia occurrence was observed in participants receiving the highest dose [235]. GSK1325756 was also tested for safety and efficacy in influenza when co-administered with oseltamivir, a standard antiviral therapy. No severe adverse events were reported, but the efficacy data was inconclusive due to the limited number of participants in the study [236, 237].

SB-656933 (Elubrixin) is another compound developed to target CXCR2 that has shown inhibition of airway neutrophilia induced by ozone challenge in healthy volunteers or in subjects with cystic fibrosis (CF) [238, 239]. However, whether this agent will improve lung function and clinical symptoms remains to be demonstrated.

Among all CXCR2 antagonists examined in clinical trials, SCH527123 (MK-7123; Navarixin) is one of a few which also targets CXCR1 and has been shown to impact disease outcomes. Treatment with SCH527123 at a dose of $50 \mathrm{mg}$ in COPD patients for 6 months decreased airway neutrophilia and resulted in a significant improvement in lung function (forced expiratory volume in $1 \mathrm{~s}$ [FEV1]) compared to placebo. Of note, the beneficial effect was only seen in active smokers [240]. The same dose of SCH527123 administered to patients with severe asthma also reduced airway PMNs and reduced asthma exacerbations [241]. However, severe neutropenia was observed in both trials, and the development of this drug for lung diseases was evidently terminated.

Formyl peptide receptors (FPRs), in particular, FPR1 and FPR2, are another family of G protein-coupled receptors expressed on PMNs that induce PMN chemotaxis, among other cellular functions. FPRs recognize $N$-formylated peptides derived from bacterial or mitochondrial proteins during acute infection or tissue injury. An elevated level of mitochondrial-derived formyl peptides with FPR activity has been detected in bronchoalveolar lavage fluid and serum of ARDS patients [242]. Moreover, recent work has suggested FPR1-mediated PMN homing to injured lung may also be involved in the development of pulmonary fibrosis [243]. These data suggest that targeting FPRs might be an attractive approach to manage neutrophilic lung diseases. Several natural and synthetic compounds with FPR antagonism have been reported [244, 245]. However, thus far, these 
antagonists have been tested only in preclinical models; further investigation is necessary to explore their potential for clinical use.

After satisfactory results in phase Ib trials, the LTB4 receptor antagonist BIIL 284 BS was tested in a randomized, double blind, multicenter, placebo-controlled phase II trial of pediatric and adult patients with CF [246]. Unfortunately, the trial was terminated early when a planned interim analysis revealed a significant increase in pulmonary-related serious adverse events in adults receiving the drug, in particular, increased respiratory signs and/or symptoms associated with pulmonary exacerbation. A study of the agent in a mouse model of $P$. aeruginosa lung infection confirmed reduced pulmonary PMNs but higher bacterial overgrowth and bacteremia [247].

\section{Targeting PMN migration through interventions on PMN-intrinsic signal transduction}

Phosphodiesterase 4 (PDE4) is a cytoplasmic enzyme that catalyzes the hydrolysis of cAMP and thereby regulates PMN migration and other functions (chemokine/cytokine synthesis, ROS release, degranulation). Inhibiting PDE4 with the small molecule roflumilast was recently shown to reduce PMN chemotaxis to CXCL1 and LTB4 through activation of EPAC1 and Rap1 in a cAMP-dependent manner [248, 249]. These findings mechanistically support the use of oral roflumilast, an agent which was approved by the FDA in 2011 for the treatment of COPD, particularly for patients with symptoms of bronchitis and frequent exacerbations. It was shown in these patients that roflumilast effectively suppresses sputum neutrophilia, improves FEV1, and reduces exacerbation rate. A series of additional PDE4 inhibitors designed for inhaled delivery have since been developed, and some have advanced into clinical trials [250]. Among these, CHF6001 has shown promising anti-inflammatory effects in COPD [251] and in atopic asthmatics, where it resulted in attenuation of the late asthmatic response in patients after allergen challenge [252]. Importantly, given the local delivery of CHF6001 to lungs, the observed drug effects may be more restricted [253], thus minimizing side effects caused by systemic agents.

Phosphoinositide 3-kinases (PI3Ks) are lipid kinases that regulate several core cellular functions, including proliferation, differentiation, survival, metabolism, and motility. As discussed above, PI3Ks have been shown to play an important role in PMN chemotaxis. Several studies have shown potential for preclinical PI3K pan-inhibitors and PI3K $\delta$ inhibitors to reduce airspace neutrophilia and other inflammatory measures in mouse models of allergic asthma [254]. A recent study showed that an inhaled prodrug PI3K inhibitor, CL27c, reduced airway inflammation, including airspace neutrophilia in a mouse model of asthma and also reduced neutrophilic inflammation and lung fibrosis induced by bleomycin [255]. Of interest, impaired PMN directional migration in healthy older adults, a potential cause of increased bystander tissue damage, has been linked to increased PI3K signaling and shown to be correctable by inhibition of PI3K $\gamma$

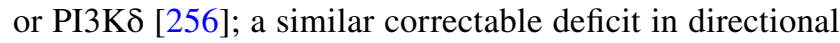
chemotaxis was also noted in PMNs from COPD patients [218]. Although these studies suggest the potential for PI3K inhibition as a strategy for modulating or optimizing PMN traffic to the lung in humans, it remains unclear whether the pleiotropic actions of PI3K inhibitors will complicate their development as lung disease therapeutics.

\section{Targeting PMN migration with statins}

HMG-CoA reductase inhibitors (i.e., 'statins') are widely used for cardiovascular disease prevention and treatment. In addition to their well-known cholesterol-reducing effects, statins also possess broad-spanning effects on inflammation and have been shown to inhibit PMN migration to the lung in mice and humans [257-261]. Despite their therapeutic potential in neutrophilic lung disease, negative results were obtained in two large-scale randomized controlled trials in ARDS: HARP-2 and SAILS [262, 263]. More recent posthoc analyses of these trials found that statin therapy provided a survival benefit in the subgroup of ARDS patients with hyperinflammatory features [264]. Statins have also shown mixed results in studies of COPD [265], but may benefit a subset of COPD patients with cardiovascular disease or exhibiting a high level of C-reactive protein, a marker for systemic inflammation [263, 266, 267]. It has been shown, somewhat paradoxically, that simvastatin may correct the deficient directional PMN migration observed in patients with COPD [265] and also in healthy, older human subjects, especially during infections such as pneumonia [268, 269]. Statins have also been shown to potentially augment the release of antibacterial PMN extracellular traps [270]. Collectively, these studies indicate a potential for statins as PMN-targeting agents in human lung disease, but suggest that patient subphenotyping, potentially involving biomarkers and/or studies of PMN function, may be required to optimize the selection of patients.

\section{Targeting PMN retention in inflamed lungs through the CXCR4/CXCL12 axis}

CXCR4/CXCL12 is a well-defined signaling axis that regulates PMN retention in the bone marrow. Administration of granulocyte colony-stimulating factor (G-CSF), which reduces CXCR4 expression on PMNs, or the CXCR4 antagonist, AMD3100 (plerixafor), to disrupt the engagement between CXCR4 and CXCL12 on bone marrow stromal cells, results in rapid release of PMNs from the bone 
marrow to the circulation. Interestingly, growing evidence suggests that CXCR4/CXCL12 may also regulate PMN activities within the lungs. In the setting of lung infection/ injury, extravascular PMNs reportedly regain CXCR4 surface expression, allowing them to accumulate in inflamed areas where there is increased expression of CXCL12 [271]. Blockade of this pathway suppresses PMN accumulation, perhaps partially due to enhancement of PMN 'reverse transmigration' [271, 272]. High CXCR4 presentation has been reported on lung-infiltrated PMNs from several unresolved human chronic lung inflammatory diseases [273]. Application of AMD3100 locally in diseased lungs to intervene upon CXCR4/CXCL12 may thus have the potential for alleviating PMN retention during resolution of inflammatory lung diseases.

\section{Other strategies}

Less selective anti-inflammatory strategies that impact PMN migration to the lung, including macrolides and anticytokine biologics have also been tested [274]. In addition to strategies for modulating PMN trafficking to the lung, several PMN effector molecules have also been targeted over the years in an effort to mitigate neutrophil-mediated inflammation in the lungs and other organs. Examples include PMN elastase inhibitors, myeloperoxidase inhibitors, and MMP inhibitors [274, 275]. Due to their robust infiltration of the inflamed lung, PMNs have themselves also been tested in preclinical models as vehicles for nanoparticle drug delivery to the lung [276].

A final complication for therapeutic development that is worth noting is that PMNs can undergo marked functional and phenotypic changes after recruitment to the airspace. This is particularly well documented in the CF airway, where PMNs exhibit enhanced degranulation and oxidant generation (potentially exacerbating lung injury) but impaired bacterial killing [277]. This PMN phenotype, recently coined 'GRIM' (granule releasing, immunomodulatory, metabolically active), can be mimicked in vitro by inducing PMN TEpM with CF airway secretions [278]. Tractable model systems such as this carry promise for identifying the molecular component(s) of CF sputum that reprogram airspace PMNs as well as for facilitating therapeutic screens.

\section{Conclusions}

The lung has unique anatomic features that reflect the mandates of gas exchange, in particular, a highly complex, redundant, narrow-caliber capillary network that is separated by just one cell layer (the alveolar epithelium) from the environment. Perhaps as a consequence, the lung shares a unique relationship with the circulating PMN. In health, PMNs, in numbers that far exceed that in the peripheral circulation, reside within the lung vasculature, patrolling the extensive endovascular surface for bacteria and then completing their life cycle. During infection, rapid and robust recruitment of PMNs through the pulmonary endothelium and then epithelium into the airspace needs to be balanced with the risk of collateral PMN-mediated tissue damage. Although several molecular checkpoints at the level of the endothelium and epithelium have been identified in the PMNs journey to the airspace, fundamental questions remain for the field (see "Box: outstanding questions"). Layered on top of this, emerging studies that have challenged the traditional monolithic view of the PMN as a simple vector of degradative cargo suggest that a more nuanced understanding of the PMN in pulmonary homeostasis will be required. Taken together, these studies suggest, in principle, the exciting opportunity to manipulate both the intrapulmonary localization and local programming of the PMN to therapeutic benefit. In upcoming years, it is expected that research questions centered on the PMN and on the lung will reciprocally and fundamentally enrich our understanding of the biology of the other.

\section{Box: outstanding questions}

What are the local niche signals in the lung that sequentially program the tissue-compartmental localization and function of PMNs during pneumonia and its resolution?

Do pulmonary interstitial fibroblasts directly and/or indirectly regulate the transendothelial and transepithelial passage of PMNs in the lung?

Are there distinct subsets of PMNs that subserve destructive, antimicrobial, and repair roles in the lung?

How do intrapulmonary PMNs and the lung microbiota reciprocally interact during health and chronic lung disease?

Are there therapeutic strategies that can be leveraged to selectively intervene upon PMN traffic to the lung in isolation from other organs?

Are there molecular strategies that can be leveraged to selectively manipulate PMN number within the pulmonary intravascular, interstitial, and intra-alveolar compartments?

What is the relative importance of interstitial vs. intra-alveolar PMNs to host defense during pneumonia?

How does transepithelial traffic of PMNs impact intrapulmonary compartmentalization and clearance of pathogens during pneumonia?

What role does efferocytic clearance of apoptotic PMNs play in pathogen killing in the infected lung?

Acknowledgements Not applicable.

Author contributions Both authors contributed to the literature review and writing of the manuscript. 
Funding This research was supported by the Intramural Research Program of the National Institutes of Health, NIEHS (Z01 ES102005).

\section{Compliance with ethical standards}

Conflict of interest The authors declare that they have no conflict of interest.

\section{References}

1. Doerschuk CM, Allard MF, Martin BA, MacKenzie A, Autor AP, Hogg JC (1987) Marginated pool of neutrophils in rabbit lungs. J Appl Physiol 63(5):1806-1815. https://doi.org/10.1152/jappl .1987.63.5.1806

2. Doerschuk CM (2001) Mechanisms of leukocyte sequestration in inflamed lungs. Microcirculation 8(2):71-88

3. Patel BV, Tatham KC, Wilson MR, O'Dea KP, Takata M (2015) In vivo compartmental analysis of leukocytes in mouse lungs. Am J Physiol Lung Cell Mol Physiol 309(7):L639-652. https:// doi.org/10.1152/ajplung.00140.2015

4. Barletta KE, Cagnina RE, Wallace KL, Ramos SI, Mehrad B, Linden J (2012) Leukocyte compartments in the mouse lung: distinguishing between marginated, interstitial, and alveolar cells in response to injury. J Immunol Methods 375(1-2):100-110. https://doi.org/10.1016/j.jim.2011.09.013

5. Yipp BG, Kim JH, Lima R, Zbytnuik LD, Petri B, Swanlund N, Ho M, Szeto VG, Tak T, Koenderman L, Pickkers P, Tool ATJ, Kuijpers TW, van den Berg TK, Looney MR, Krummel MF, Kubes $P$ (2017) The lung is a host defense niche for immediate neutrophil-mediated vascular protection. Sci Immunol. https:// doi.org/10.1126/sciimmunol.aam8929

6. Reutershan J, Basit A, Galkina EV, Ley K (2005) Sequential recruitment of neutrophils into lung and bronchoalveolar lavage fluid in LPS-induced acute lung injury. Am J Physiol Lung Cell Mol Physiol 289(5):L807-815. https://doi.org/10.1152/ajplu ng.00477.2004

7. Kreisel D, Nava RG, Li W, Zinselmeyer BH, Wang B, Lai J, Pless R, Gelman AE, Krupnick AS, Miller MJ (2010) In vivo twophoton imaging reveals monocyte-dependent neutrophil extravasation during pulmonary inflammation. Proc Natl Acad Sci USA 107(42):18073-18078. https://doi.org/10.1073/pnas.1008737107

8. Doyle NA, Bhagwan SD, Meek BB, Kutkoski GJ, Steeber DA, Tedder TF, Doerschuk CM (1997) Neutrophil margination, sequestration, and emigration in the lungs of L-selectin-deficient mice. J Clin Investig 99(3):526-533. https://doi.org/10.1172/ JCI119189

9. Doerschuk CM, Quinlan WM, Doyle NA, Bullard DC, Vestweber D, Jones ML, Takei F, Ward PA, Beaudet AL (1996) The role of P-selectin and ICAM-1 in acute lung injury as determined using blocking antibodies and mutant mice. J Immunol 157(10):4609-4614

10. Mizgerd JP, Meek BB, Kutkoski GJ, Bullard DC, Beaudet AL, Doerschuk CM (1996) Selectins and neutrophil traffic: margination and Streptococcus pneumoniae-induced emigration in murine lungs. J Exp Med 184(2):639-645. https://doi. org/10.1084/jem.184.2.639

11. Devi S, Wang Y, Chew WK, Lima R, A-González N, Mattar CN, Chong SZ, Schlitzer A, Bakocevic N, Chew S, Keeble JL, Goh CC, Li JL, Evrard M, Malleret B, Larbi A, Renia L, Haniffa M, Tan SM, Chan JK, Balabanian K, Nagasawa T, Bachelerie F, Hidalgo A, Ginhoux F, Kubes P, Ng LG (2013) Neutrophil mobilization via plerixafor-mediated CXCR4 inhibition arises from lung demargination and blockade of neutrophil homing to the bone marrow. J Exp Med 210(11):2321-2336. https://doi. org/10.1084/jem.20130056

12. Liu Q, Li Z, Gao JL, Wan W, Ganesan S, McDermott DH, Murphy PM (2015) CXCR4 antagonist AMD3100 redistributes leukocytes from primary immune organs to secondary immune organs, lung, and blood in mice. Eur J Immunol 45(6):18551867. https://doi.org/10.1002/eji.201445245

13. Kim JH, Podstawka J, Lou Y, Li L, Lee EKS, Divangahi M, Petri B, Jirik FR, Kelly MM, Yipp BG (2018) Aged polymorphonuclear leukocytes cause fibrotic interstitial lung disease in the absence of regulation by B cells. Nat Immunol 19(2):192-201. https://doi.org/10.1038/s41590-017-0030-x

14. Uhl B, Vadlau Y, Zuchtriegel G, Nekolla K, Sharaf K, Gaertner F, Massberg S, Krombach F, Reichel CA (2016) Aged neutrophils contribute to the first line of defense in the acute inflammatory response. Blood 128(19):2327-2337. https://doi.org/10.1182/ blood-2016-05-718999

15. Doerschuk CM (1992) The role of CD18-mediated adhesion in neutrophil sequestration induced by infusion of activated plasma in rabbits. Am J Respir Cell Mol Biol 7(2):140-148. https://doi. org/10.1165/ajrcmb/7.2.140

16. Kubo H, Doyle NA, Graham L, Bhagwan SD, Quinlan WM, Doerschuk CM (1999) L- and P-selectin and CD11/CD18 in intracapillary neutrophil sequestration in rabbit lungs. Am J Respir Crit Care Med 159(1):267-274. https://doi.org/10.1164/ ajrccm.159.1.9709011

17. Warburton D, Schwarz M, Tefft D, Flores-Delgado G, Anderson KD, Cardoso WV (2000) The molecular basis of lung morphogenesis. Mech Dev 92(1):55-81. https://doi.org/10.1016/s0925 -4773(99)00325-1

18. Burns AR, Smith CW, Walker DC (2003) Unique structural features that influence neutrophil emigration into the lung. Physiol Rev 83(2):309-336. https://doi.org/10.1152/physrev.00023.2002

19. Downey GP, Worthen GS, Henson PM, Hyde DM (1993) Neutrophil sequestration and migration in localized pulmonary inflammation. Capillary localization and migration across the interalveolar septum. Am Rev Respir Dis 147(1):168-176. https ://doi.org/10.1164/ajrccm/147.1.168

20. Behzad AR, Chu F, Walker DC (1996) Fibroblasts are in a position to provide directional information to migrating neutrophils during pneumonia in rabbit lungs. Microvasc Res 51(3):303-316. https://doi.org/10.1006/mvre.1996.0029

21. Walker DC, Behzad AR, Chu F (1995) Neutrophil migration through preexisting holes in the basal laminae of alveolar capillaries and epithelium during streptococcal pneumonia. Microvasc Res 50(3):397-416. https://doi.org/10.1006/mvre.1995.1067

22. Damiano VV, Cohen A, Tsang AL, Batra G, Petersen R (1980) A morphologic study of the influx of neutrophils into dog lung alveoli after lavage with sterile saline. Am J Pathol 100(2):349-364

23. Burns AR, Walker DC, Brown ES, Thurmon LT, Bowden RA, Keese CR, Simon SI, Entman ML, Smith CW (1997) Neutrophil transendothelial migration is independent of tight junctions and occurs preferentially at tricellular corners. J Immunol 159(6):2893-2903

24. Wang PM, Kachel DL, Cesta MF, Martin WJ 2nd (2011) Direct leukocyte migration across pulmonary arterioles and venules into the perivascular interstitium of murine lungs during bleomycin injury and repair. Am J Pathol 178(6):2560-2572. https://doi. org/10.1016/j.ajpath.2011.02.047

25. Konrad FM, Wohlert J, Gamper-Tsigaras J, Ngamsri KC, Reutershan J (2019) How adhesion molecule patterns change while neutrophils traffic through the lung during inflammation. Mediat Inflamm 2019:1208086. https://doi.org/10.1155/2019/1208086

26. Alcamo E, Mizgerd JP, Horwitz BH, Bronson R, Beg AA, Scott M, Doerschuk CM, Hynes RO, Baltimore D (2001) Targeted mutation of TNF receptor I rescues the RelA-deficient mouse and 
reveals a critical role for NF-kappa B in leukocyte recruitment. J Immunol 167(3):1592-1600. https://doi.org/10.4049/jimmu nol.167.3.1592

27. Poynter ME, Irvin CG, Janssen-Heininger YM (2003) A prominent role for airway epithelial NF-kappa B activation in lipopolysaccharide-induced airway inflammation. J Immunol 170(12):6257-6265. https://doi.org/10.4049/jimmu nol.170.12.6257

28. Quinton LJ, Jones MR, Simms BT, Kogan MS, Robson BE, Skerrett SJ, Mizgerd JP (2007) Functions and regulation of NF-kappaB RelA during pneumococcal pneumonia. J Immunol 178(3):1896-1903. https://doi.org/10.4049/jimmunol.178.3.1896

29. Skerrett SJ, Liggitt HD, Hajjar AM, Ernst RK, Miller SI, Wilson CB (2004) Respiratory epithelial cells regulate lung inflammation in response to inhaled endotoxin. Am J Physiol Lung Cell Mol Physiol 287(1):L143-152. https://doi.org/10.1152/ajplu ng.00030.2004

30. Balamayooran G, Batra S, Fessler MB, Happel KI, Jeyaseelan $S$ (2010) Mechanisms of neutrophil accumulation in the lungs against bacteria. Am J Respir Cell Mol Biol 43(1):5-16. https:// doi.org/10.1165/rcmb.2009-0047TR

31. Bhatia M, Zemans RL, Jeyaseelan S (2012) Role of chemokines in the pathogenesis of acute lung injury. Am J Respir Cell Mol Biol 46(5):566-572. https://doi.org/10.1165/rcmb.2011-0392TR

32. Reutershan J, Morris MA, Burcin TL, Smith DF, Chang D, Saprito MS, Ley K (2006) Critical role of endothelial CXCR2 in LPS-induced neutrophil migration into the lung. J Clin Investig 116(3):695-702. https://doi.org/10.1172/JCI27009

33. Yamamoto K, Ferrari JD, Cao Y, Ramirez MI, Jones MR, Quinton LJ, Mizgerd JP (2012) Type I alveolar epithelial cells mount innate immune responses during pneumococcal pneumonia. $\mathrm{J}$ Immunol 189(5):2450-2459. https://doi.org/10.4049/jimmu nol.1200634

34. Jeyaseelan S, Manzer R, Young SK, Yamamoto M, Akira S, Mason RJ, Worthen GS (2005) Induction of CXCL5 during inflammation in the rodent lung involves activation of alveolar epithelium. Am J Respir Cell Mol Biol 32(6):531-539. https:// doi.org/10.1165/rcmb.2005-0063OC

35. Gibbs J, Ince L, Matthews L, Mei J, Bell T, Yang N, Saer B, Begley N, Poolman T, Pariollaud M, Farrow S, DeMayo F, Hussell T, Worthen GS, Ray D, Loudon A (2014) An epithelial circadian clock controls pulmonary inflammation and glucocorticoid action. Nat Med 20(8):919-926. https://doi.org/10.1038/nm.3599

36. Rossi DL, Hurst SD, Xu Y, Wang W, Menon S, Coffman RL, Zlotnik A (1999) Lungkine, a novel CXC chemokine, specifically expressed by lung bronchoepithelial cells. J Immunol 162(9):5490-5497

37. Chen SC, Mehrad B, Deng JC, Vassileva G, Manfra DJ, Cook DN, Wiekowski MT, Zlotnik A, Standiford TJ, Lira SA (2001) Impaired pulmonary host defense in mice lacking expression of the CXC chemokine lungkine. J Immunol 166(5):3362-3368. https://doi.org/10.4049/jimmunol.166.5.3362

38. Jeyaseelan S, Chu HW, Young SK, Worthen GS (2004) Transcriptional profiling of lipopolysaccharide-induced acute lung injury. Infect Immun 72(12):7247-7256. https://doi.org/10.1128/ IAI.72.12.7247-7256.2004

39. Mei J, Liu Y, Dai N, Favara M, Greene T, Jeyaseelan S, Poncz M, Lee JS, Worthen GS (2010) CXCL5 regulates chemokine scavenging and pulmonary host defense to bacterial infection. Immunity 33(1):106-117. https://doi.org/10.1016/j.immun i.2010.07.009

40. Ye P, Rodriguez FH, Kanaly S, Stocking KL, Schurr J, Schwarzenberger P, Oliver P, Huang W, Zhang P, Zhang J, Shellito JE, Bagby GJ, Nelson S, Charrier K, Peschon JJ, Kolls JK (2001) Requirement of interleukin 17 receptor signaling for lung CXC chemokine and granulocyte colony-stimulating factor expression, neutrophil recruitment, and host defense. J Exp Med 194(4):519-527. https://doi.org/10.1084/jem.194.4.519

41. Eddens T, Kolls JK (2012) Host defenses against bacterial lower respiratory tract infection. Curr Opin Immunol 24(4):424-430. https://doi.org/10.1016/j.coi.2012.07.005

42. Liu Y, Mei J, Gonzales L, Yang G, Dai N, Wang P, Zhang P, Favara M, Malcolm KC, Guttentag S, Worthen GS (2011) IL$17 \mathrm{~A}$ and TNF-alpha exert synergistic effects on expression of CXCL5 by alveolar type II cells in vivo and in vitro. J Immunol 186(5):3197-3205. https://doi.org/10.4049/jimmunol.1002016

43. Chen K, McAleer JP, Lin Y, Paterson DL, Zheng M, Alcorn JF, Weaver CT, Kolls JK (2011) Th17 cells mediate clade-specific, serotype-independent mucosal immunity. Immunity 35(6):9971009. https://doi.org/10.1016/j.immuni.2011.10.018

44. Michel ML, Keller AC, Paget C, Fujio M, Trottein F, Savage PB, Wong CH, Schneider E, Dy M, Leite-de-Moraes MC (2007) Identification of an IL-17-producing NK1.1(neg) iNKT cell population involved in airway neutrophilia. J Exp Med 204(5):9951001. https://doi.org/10.1084/jem.20061551

45. Cheng P, Liu T, Zhou WY, Zhuang Y, Peng LS, Zhang JY, Yin ZN, Mao XH, Guo G, Shi Y, Zou QM (2012) Role of gamma-delta $\mathrm{T}$ cells in host response against Staphylococcus aureus-induced pneumonia. BMC Immunol 13:38. https://doi. org/10.1186/1471-2172-13-38

46. Martin B, Hirota K, Cua DJ, Stockinger B, Veldhoen M (2009) Interleukin-17-producing gammadelta $\mathrm{T}$ cells selectively expand in response to pathogen products and environmental signals. Immunity 31(2):321-330. https://doi.org/10.1016/j.immun i.2009.06.020

47. Sutton CE, Lalor SJ, Sweeney CM, Brereton CF, Lavelle EC, Mills KH (2009) Interleukin-1 and IL-23 induce innate IL-17 production from gammadelta $\mathrm{T}$ cells, amplifying Th17 responses and autoimmunity. Immunity 31(2):331-341. https://doi. org/10.1016/j.immuni.2009.08.001

48. Happel KI, Zheng M, Young E, Quinton LJ, Lockhart E, Ramsay AJ, Shellito JE, Schurr JR, Bagby GJ, Nelson S, Kolls JK (2003) Cutting edge: roles of Toll-like receptor 4 and IL-23 in IL-17 expression in response to Klebsiella pneumoniae infection. J Immunol 170(9):4432-4436. https://doi.org/10.4049/jimmu nol.170.9.4432

49. Bhan U, Ballinger MN, Zeng X, Newstead MJ, Cornicelli MD, Standiford TJ (2010) Cooperative interactions between TLR4 and TLR9 regulate interleukin 23 and 17 production in a murine model of gram negative bacterial pneumonia. PLoS ONE 5(3):e9896. https://doi.org/10.1371/journal.pone.0009896

50. Weathington NM, van Houwelingen AH, Noerager BD, Jackson PL, Kraneveld AD, Galin FS, Folkerts G, Nijkamp FP, Blalock JE (2006) A novel peptide CXCR ligand derived from extracellular matrix degradation during airway inflammation. Nat Med 12(3):317-323. https://doi.org/10.1038/nm1361

51. Gaggar A, Jackson PL, Noerager BD, O'Reilly PJ, McQuaid DB, Rowe SM, Clancy JP, Blalock JE (2008) A novel proteolytic cascade generates an extracellular matrix-derived chemoattractant in chronic neutrophilic inflammation. J Immunol 180(8):56625669. https://doi.org/10.4049/jimmunol.180.8.5662

52. Sharma NS, Lal CV, Li JD, Lou XY, Viera L, Abdallah T, King RW, Sethi J, Kanagarajah P, Restrepo-Jaramillo R, Sales-Conniff A, Wei S, Jackson PL, Blalock JE, Gaggar A, Xu X (2018) The neutrophil chemoattractant peptide proline-glycine-proline is associated with acute respiratory distress syndrome. Am J Physiol Lung Cell Mol Physiol 315(5):L653-L661. https://doi. org/10.1152/ajplung.00308.2017

53. Wells JM, Xing D, Viera L, Burkes RM, Wu Y, Bhatt SP, Dransfield MT, Couper DJ, O’Neal W, Hoffman EA, Gaggar A, Barjaktarevic I, Curtis JL, Labaki WW, Han MLK, Freeman CM, Putcha N, Schlange T, Blalock JE, Investigators S 
(2019) The matrikine acetyl-proline-glycine-proline and clinical features of COPD: findings from SPIROMICS. Respir Res 20(1):254. https://doi.org/10.1186/s12931-019-1230-8

54. Akthar S, Patel DF, Beale RC, Peiro T, Xu X, Gaggar A, Jackson PL, Blalock JE, Lloyd CM, Snelgrove RJ (2015) Matrikines are key regulators in modulating the amplitude of lung inflammation in acute pulmonary infection. Nat Commun 6:8423. https://doi.org/10.1038/ncomms 9423

55. Snelgrove RJ, Jackson PL, Hardison MT, Noerager BD, Kinloch A, Gaggar A, Shastry S, Rowe SM, Shim YM, Hussell T, Blalock JE (2010) A critical role for LTA4H in limiting chronic pulmonary neutrophilic inflammation. Science 330(6000):9094. https://doi.org/10.1126/science.1190594

56. Crooks SW, Stockley RA (1998) Leukotriene B4. Int J Biochem Cell Biol 30(2):173-178. https://doi.org/10.1016/s1357 -2725(97)00123-4

57. Gelfand EW (2017) Importance of the leukotriene B4-BLT1 and LTB4-BLT2 pathways in asthma. Semin Immunol 33:4451. https://doi.org/10.1016/j.smim.2017.08.005

58. Batra S, Cai S, Balamayooran G, Jeyaseelan S (2012) Intrapulmonary administration of leukotriene $\mathrm{B}(4)$ augments neutrophil accumulation and responses in the lung to Klebsiella infection in CXCL1 knockout mice. J Immunol 188(7):34583468. https://doi.org/10.4049/jimmunol.1101985

59. Yonker LM, Pazos MA, Lanter BB, Mou H, Chu KK, Eaton AD, Bonventre JV, Tearney GJ, Rajagopal J, Hurley BP (2017) Neutrophil-derived cytosolic PLA2alpha contributes to bacterial-induced neutrophil transepithelial migration. J Immunol 199(8):2873-2884. https://doi.org/10.4049/jimmunol.1700539

60. Hicks A, Goodnow R Jr, Cavallo G, Tannu SA, Ventre JD, Lavelle D, Lora JM, Satjawatcharaphong J, Brovarney M, Dabbagh K, Tare NS, Oh H, Lamb M, Sidduri A, Dominique R, Qiao Q, Lou JP, Gillespie P, Fotouhi N, Kowalczyk A, Kurylko G, Hamid R, Wright MB, Pamidimukkala A, Egan T, Gubler U, Hoffman AF, Wei X, Li YL, O'Neil J, Marcano R, Pozzani K, Molinaro T, Santiago J, Singer L, Hargaden M, Moore D, Catala AR, Chao LC, Benson J, March T, Venkat R, Mancebo H, Renzetti LM (2010) Effects of LTB4 receptor antagonism on pulmonary inflammation in rodents and non-human primates. Prostaglandins Other Lipid Mediat 92(1-4):33-43. https ://doi.org/10.1016/j.prostaglandins.2010.02.003

61. Xiao Q, Dong N, Yao X, Wu D, Lu Y, Mao F, Zhu J, Li J, Huang J, Chen A, Huang L, Wang X, Yang G, He G, Xu Y, Lu W (2016) Bufexamac ameliorates LPS-induced acute lung injury in mice by targeting LTA4H. Sci Rep 6:25298. https:// doi.org/10.1038/srep25298

62. Mrsny RJ, Gewirtz AT, Siccardi D, Savidge T, Hurley BP, Madara JL, McCormick BA (2004) Identification of hepoxilin A3 in inflammatory events: a required role in neutrophil migration across intestinal epithelia. Proc Natl Acad Sci USA 101(19):7421-7426. https://doi.org/10.1073/pnas.0400832101

63. Hurley BP, Siccardi D, Mrsny RJ, McCormick BA (2004) Polymorphonuclear cell transmigration induced by Pseudomonas aeruginosa requires the eicosanoid hepoxilin A3. J Immunol 173(9):5712-5720. https://doi.org/10.4049/jimmu nol.173.9.5712

64. Tamang DL, Pirzai W, Priebe GP, Traficante DC, Pier GB, Falck JR, Morisseau C, Hammock BD, McCormick BA, Gronert K, Hurley BP (2012) Hepoxilin A(3) facilitates neutrophilic breach of lipoxygenase-expressing airway epithelial barriers. J Immunol 189(10):4960-4969. https://doi.org/10.4049/jimmunol.1201922

65. Kubala SA, Patil SU, Shreffler WG, Hurley BP (2014) Pathogen induced chemo-attractant hepoxilin A3 drives neutrophils, but not eosinophils across epithelial barriers. Prostaglandins Other Lipid Mediat 108:1-8. https://doi.org/10.1016/j.prostaglan dins.2013.11.001
66. Pazos MA, Pirzai W, Yonker LM, Morisseau C, Gronert K, Hurley BP (2015) Distinct cellular sources of hepoxilin A3 and leukotriene B4 are used to coordinate bacterial-induced neutrophil transepithelial migration. J Immunol 194(3):1304-1315. https:// doi.org/10.4049/jimmunol.1402489

67. Lortat-Jacob H, Grosdidier A, Imberty A (2002) Structural diversity of heparan sulfate binding domains in chemokines. Proc Natl Acad Sci USA 99(3):1229-1234. https://doi.org/10.1073/ pnas.032497699

68. Lau EK, Allen S, Hsu AR, Handel TM (2004) Chemokinereceptor interactions: GPCRs, glycosaminoglycans and viral chemokine binding proteins. Adv Protein Chem 68:351-391. https://doi.org/10.1016/S0065-3233(04)68010-7

69. Li Q, Park PW, Wilson CL, Parks WC (2002) Matrilysin shedding of syndecan-1 regulates chemokine mobilization and transepithelial efflux of neutrophils in acute lung injury. Cell 111(5):635-646. https://doi.org/10.1016/s0092-8674(02)01079 $-6$

70. Tanino Y, Coombe DR, Gill SE, Kett WC, Kajikawa O, Proudfoot AE, Wells TN, Parks WC, Wight TN, Martin TR, Frevert CW (2010) Kinetics of chemokine-glycosaminoglycan interactions control neutrophil migration into the airspaces of the lungs. J Immunol 184(5):2677-2685. https://doi.org/10.4049/jimmu nol.0903274

71. Quinton LJ, Nelson S, Zhang P, Boe DM, Happel KI, Pan W, Bagby GJ (2004) Selective transport of cytokine-induced neutrophil chemoattractant from the lung to the blood facilitates pulmonary neutrophil recruitment. Am J Physiol Lung Cell Mol Physiol 286(3):L465-472. https://doi.org/10.1152/ajplung.00153 .2003

72. Campbell JJ, Foxman EF, Butcher EC (1997) Chemoattractant receptor cross talk as a regulatory mechanism in leukocyte adhesion and migration. Eur J Immunol 27(10):2571-2578. https:// doi.org/10.1002/eji.1830271016

73. Foxman EF, Campbell JJ, Butcher EC (1997) Multistep navigation and the combinatorial control of leukocyte chemotaxis. J Cell Biol 139(5):1349-1360. https://doi.org/10.1083/ jcb.139.5.1349

74. Heit B, Tavener S, Raharjo E, Kubes P (2002) An intracellular signaling hierarchy determines direction of migration in opposing chemotactic gradients. J Cell Biol 159(1):91-102. https://doi. org/10.1083/jcb.200202114

75. Heit B, Robbins SM, Downey CM, Guan Z, Colarusso P, Miller BJ, Jirik FR, Kubes P (2008) PTEN functions to 'prioritize' chemotactic cues and prevent "distraction" in migrating neutrophils. Nat Immunol 9(7):743-752. https://doi.org/10.1038/ ni. 1623

76. Middleton J, Neil S, Wintle J, Clark-Lewis I, Moore H, Lam C, Auer M, Hub E, Rot A (1997) Transcytosis and surface presentation of IL-8 by venular endothelial cells. Cell 91(3):385-395. https://doi.org/10.1016/s0092-8674(00)80422-5

77. Wang L, Fuster M, Sriramarao P, Esko JD (2005) Endothelial heparan sulfate deficiency impairs L-selectin- and chemokinemediated neutrophil trafficking during inflammatory responses. Nat Immunol 6(9):902-910. https://doi.org/10.1038/ni1233

78. Pruenster M, Mudde L, Bombosi P, Dimitrova S, Zsak M, Middleton J, Richmond A, Graham GJ, Segerer S, Nibbs RJ, Rot A (2009) The Duffy antigen receptor for chemokines transports chemokines and supports their promigratory activity. Nat Immunol 10(1):101-108. https://doi.org/10.1038/ni.1675

79. Lee JS, Frevert CW, Wurfel MM, Peiper SC, Wong VA, Ballman KK, Ruzinski JT, Rhim JS, Martin TR, Goodman RB (2003) Duffy antigen facilitates movement of chemokine across the endothelium in vitro and promotes neutrophil transmigration in vitro and in vivo. J Immunol 170(10):5244-5251. https://doi. org/10.4049/jimmunol.170.10.5244 
80. Lee JS, Wurfel MM, Matute-Bello G, Frevert CW, Rosengart MR, Ranganathan M, Wong VW, Holden T, Sutlief S, Richmond A, Peiper S, Martin TR (2006) The Duffy antigen modifies systemic and local tissue chemokine responses following lipopolysaccharide stimulation. J Immunol 177(11):8086-8094. https:// doi.org/10.4049/jimmunol.177.11.8086

81. Reutershan J, Harry B, Chang D, Bagby GJ, Ley K (2009) DARC on RBC limits lung injury by balancing compartmental distribution of CXC chemokines. Eur J Immunol 39(6):1597-1607. https ://doi.org/10.1002/eji.200839089

82. Hol J, Wilhelmsen L, Haraldsen G (2010) The murine IL-8 homologues KC, MIP-2, and LIX are found in endothelial cytoplasmic granules but not in Weibel-Palade bodies. J Leukoc Biol 87(3):501-508. https://doi.org/10.1189/jlb.0809532

83. Ley K, Laudanna C, Cybulsky MI, Nourshargh S (2007) Getting to the site of inflammation: the leukocyte adhesion cascade updated. Nat Rev Immunol 7(9):678-689. https://doi. org/10.1038/nri2156

84. Griffin GK, Newton G, Tarrio ML, Bu DX, Maganto-Garcia E, Azcutia V, Alcaide P, Grabie N, Luscinskas FW, Croce KJ, Lichtman AH (2012) IL-17 and TNF-alpha sustain neutrophil recruitment during inflammation through synergistic effects on endothelial activation. J Immunol 188(12):6287-6299. https:// doi.org/10.4049/jimmunol.1200385

85. Yao L, Yago T, Shao B, Liu Z, Silasi-Mansat R, Setiadi H, Lupu F, McEver RP (2013) Elevated CXCL1 expression in gp130deficient endothelial cells impairs neutrophil migration in mice. Blood 122(23):3832-3842. https://doi.org/10.1182/blood-2012$12-473835$

86. Brandes M, Klauschen F, Kuchen S, Germain RN (2013) A systems analysis identifies a feedforward inflammatory circuit leading to lethal influenza infection. Cell 154(1):197-212. https ://doi.org/10.1016/j.cell.2013.06.013

87. Ichikawa A, Kuba K, Morita M, Chida S, Tezuka H, Hara H, Sasaki T, Ohteki T, Ranieri VM, dos Santos CC, Kawaoka Y, Akira S, Luster AD, Lu B, Penninger JM, Uhlig S, Slutsky AS, Imai Y (2013) CXCL10-CXCR3 enhances the development of neutrophil-mediated fulminant lung injury of viral and nonviral origin. Am J Respir Crit Care Med 187(1):65-77. https://doi. org/10.1164/rccm.201203-0508OC

88. Kienle K, Lammermann T (2016) Neutrophil swarming: an essential process of the neutrophil tissue response. Immunol Rev 273(1):76-93. https://doi.org/10.1111/imr.12458

89. Petri B, Phillipson M, Kubes P (2008) The physiology of leukocyte recruitment: an in vivo perspective. J Immunol 180(10):6439-6446. https://doi.org/10.4049/jimmu nol.180.10.6439

90. Maas SL, Soehnlein O, Viola JR (2018) Organ-specific mechanisms of transendothelial neutrophil migration in the lung, liver, kidney, and aorta. Front Immunol 9:2739. https://doi. org/10.3389/fimmu.2018.02739

91. Doerschuk CM, Beyers N, Coxson HO, Wiggs B, Hogg JC (1993) Comparison of neutrophil and capillary diameters and their relation to neutrophil sequestration in the lung. J Appl Physiol 74(6):3040-3045. https://doi.org/10.1152/jappl.1993.74.6.3040

92. Downey GP, Doherty DE, Schwab B 3rd, Elson EL, Henson PM, Worthen GS (1990) Retention of leukocytes in capillaries: role of cell size and deformability. J Appl Physiol 69(5):1767-1778. https://doi.org/10.1152/jappl.1990.69.5.1767

93. Gebb SA, Graham JA, Hanger CC, Godbey PS, Capen RL, Doerschuk CM, Wagner WW Jr (1995) Sites of leukocyte sequestration in the pulmonary microcirculation. J Appl Physiol 79(2):493-497. https://doi.org/10.1152/jappl.1995.79.2.493

94. Wiggs BR, English D, Quinlan WM, Doyle NA, Hogg JC, Doerschuk CM (1994) Contributions of capillary pathway size and neutrophil deformability to neutrophil transit through rabbit lungs. J Appl Physiol 77(1):463-470. https://doi. org/10.1152/jappl.1994.77.1.463

95. Worthen GS, Schwab B 3rd, Elson EL, Downey GP (1989) Mechanics of stimulated neutrophils: cell stiffening induces retention in capillaries. Science 245(4914):183-186. https:// doi.org/10.1126/science. 2749255

96. Bullard DC, Kunkel EJ, Kubo H, Hicks MJ, Lorenzo I, Doyle NA, Doerschuk CM, Ley K, Beaudet AL (1996) Infectious susceptibility and severe deficiency of leukocyte rolling and recruitment in E-selectin and P-selectin double mutant mice. J Exp Med 183(5):2329-2336. https://doi.org/10.1084/ jem.183.5.2329

97. Mizgerd JP, Quinlan WM, LeBlanc BW, Kutkoski GJ, Bullard DC, Beaudet AL, Doerschuk CM (1998) Combinatorial requirements for adhesion molecules in mediating neutrophil emigration during bacterial peritonitis in mice. J Leukoc Biol 64(3):291297. https://doi.org/10.1002/jlb.64.3.291

98. Kornerup KN, Salmon GP, Pitchford SC, Liu WL (2010) Circulating platelet-neutrophil complexes are important for subsequent neutrophil activation and migration. J Appl Physiol 109(3):758767. https://doi.org/10.1152/japplphysiol.01086.2009

99. Cappenberg A, Margraf A, Thomas K, Bardel B, McCreedy DA, Van Marck V, Mellmann A, Lowell CA, Zarbock A (2019) L-selectin shedding affects bacterial clearance in the lung: a new regulatory pathway for integrin outside-in signaling. Blood 134(17):1445-1457. https://doi.org/10.1182/blood.2019000685

100. Choudhury SR, Babes L, Rahn JJ, Ahn BY, Goring KR, King JC, Lau A, Petri B, Hao X, Chojnacki AK, Thanabalasuriar A, McAvoy EF, Tabaries S, Schraeder C, Patel KD, Siegel PM, Kopciuk KA, Schriemer DC, Muruve DA, Kelly MM, Yipp BG, Kubes P, Robbins SM, Senger DL (2019) Dipeptidase-1 is an adhesion receptor for neutrophil recruitment in lungs and liver. Cell 178(5):1205-1221 e1217. https://doi.org/10.1016/j. cell.2019.07.017

101. Schmidt EP, Yang Y, Janssen WJ, Gandjeva A, Perez MJ, Barthel L, Zemans RL, Bowman JC, Koyanagi DE, Yunt ZX, Smith LP, Cheng SS, Overdier KH, Thompson KR, Geraci MW, Douglas IS, Pearse DB, Tuder RM (2012) The pulmonary endothelial glycocalyx regulates neutrophil adhesion and lung injury during experimental sepsis. Nat Med 18(8):1217-1223. https://doi. org $/ 10.1038 / \mathrm{nm} .2843$

102. Begandt D, Thome S, Sperandio M, Walzog B (2017) How neutrophils resist shear stress at blood vessel walls: molecular mechanisms, subcellular structures, and cell-cell interactions. J Leukoc Biol 102(3):699-709. https://doi.org/10.1189/jlb.3MR01 17-026RR

103. Moreland JG, Fuhrman RM, Pruessner JA, Schwartz DA (2002) $\mathrm{CD} 11 \mathrm{~b}$ and intercellular adhesion molecule-1 are involved in pulmonary neutrophil recruitment in lipopolysaccharide-induced airway disease. Am J Respir Cell Mol Biol 27(4):474-480. https ://doi.org/10.1165/rcmb.4694

104. Doerschuk CM, Winn RK, Coxson HO, Harlan JM (1990) CD18dependent and -independent mechanisms of neutrophil emigration in the pulmonary and systemic microcirculation of rabbits. J Immunol 144(6):2327-2333

105. Mizgerd JP, Horwitz BH, Quillen HC, Scott ML, Doerschuk CM (1999) Effects of CD18 deficiency on the emigration of murine neutrophils during pneumonia. J Immunol 163(2):995-999

106. Kumasaka T, Doyle NA, Quinlan WM, Graham L, Doerschuk CM (1996) Role of CD 11/CD 18 in neutrophil emigration during acute and recurrent $P$ seudomonas aeruginosa-induced pneumonia in rabbits. Am J Pathol 148(4):1297-1305

107. Qin L, Quinlan WM, Doyle NA, Graham L, Sligh JE, Takei F, Beaudet AL, Doerschuk CM (1996) The roles of CD11/CD18 and ICAM-1 in acute Pseudomonas aeruginosa-induced pneumonia in mice. J Immunol 157(11):5016-5021 
108. Mizgerd JP, Kubo H, Kutkoski GJ, Bhagwan SD, ScharffetterKochanek K, Beaudet AL, Doerschuk CM (1997) Neutrophil emigration in the skin, lungs, and peritoneum: different requirements for CD11/CD18 revealed by CD18-deficient mice. J Exp Med 186(8):1357-1364. https://doi.org/10.1084/jem.186.8.1357

109. Burns AR, Takei F, Doerschuk CM (1994) Quantitation of ICAM-1 expression in mouse lung during pneumonia. J Immunol 153(7):3189-3198

110. Wilson ZS, Ahn LB, Serratelli WS, Belley MD, Lomas-Neira J, Sen M, Lefort CT (2017) Activated beta2 integrins restrict neutrophil recruitment during murine acute Pseudomonal pneumonia. Am J Respir Cell Mol Biol 56(5):620-627. https://doi. org/10.1165/rcmb.2016-0215OC

111. Ridger VC, Wagner BE, Wallace WA, Hellewell PG (2001) Differential effects of CD18, CD29, and CD49 integrin subunit inhibition on neutrophil migration in pulmonary inflammation. J Immunol 166(5):3484-3490. https://doi.org/10.4049/jimmu nol.166.5.3484

112. Tasaka S, Richer SE, Mizgerd JP, Doerschuk CM (2002) Very late antigen-4 in CD18-independent neutrophil emigration during acute bacterial pneumonia in mice. Am J Respir Crit Care Med 166(1):53-60. https://doi.org/10.1164/rccm.2105034

113. Janardhan KS, Charavaryamath C, Aulakh GK, Singh B (2012) Integrin beta3 is not critical for neutrophil recruitment in a mouse model of pneumococcal pneumonia. Cell Tissue Res 348(1):177-187. https://doi.org/10.1007/s00441-011-1300-9

114. Su X, Johansen M, Looney MR, Brown EJ, Matthay MA (2008) CD47 deficiency protects mice from lipopolysaccharideinduced acute lung injury and Escherichia coli pneumonia. J Immunol 180(10):6947-6953. https://doi.org/10.4049/jimmu nol.180.10.6947

115. Phillipson M, Heit B, Colarusso P, Liu L, Ballantyne CM, Kubes $P$ (2006) Intraluminal crawling of neutrophils to emigration sites: a molecularly distinct process from adhesion in the recruitment cascade. J Exp Med 203(12):2569-2575. https://doi.org/10.1084/ jem. 20060925

116. Phillipson M, Heit B, Parsons SA, Petri B, Mullaly SC, Colarusso P, Gower RM, Neely G, Simon SI, Kubes P (2009) Vav1 is essential for mechanotactic crawling and migration of neutrophils out of the inflamed microvasculature. J Immunol 182(11):68706878. https://doi.org/10.4049/jimmunol.0803414

117. Shaw SK, Bamba PS, Perkins BN, Luscinskas FW (2001) Realtime imaging of vascular endothelial-cadherin during leukocyte transmigration across endothelium. J Immunol 167(4):23232330. https://doi.org/10.4049/jimmunol.167.4.2323

118. Yang L, Froio RM, Sciuto TE, Dvorak AM, Alon R, Luscinskas FW (2005) ICAM-1 regulates neutrophil adhesion and transcellular migration of TNF-alpha-activated vascular endothelium under flow. Blood 106(2):584-592. https://doi.org/10.1182/blood $-2004-12-4942$

119. Cho Y, De Bruyn PP (1986) Internal structure of the postcapillary high-endothelial venules of rodent lymph nodes and Peyer's patches and the transendothelial lymphocyte passage. Am J Anat 177(4):481-490. https://doi.org/10.1002/aja.1001770406

120. Greenwood J, Howes R, Lightman S (1994) The blood-retinal barrier in experimental autoimmune uveoretinitis. Leukocyte interactions and functional damage. Lab Investig 70(1):39-52

121. Feng D, Nagy JA, Pyne K, Dvorak HF, Dvorak AM (1998) Neutrophils emigrate from venules by a transendothelial cell pathway in response to FMLP. J Exp Med 187(6):903-915. https://doi. org/10.1084/jem.187.6.903

122. Hoshi O, Ushiki T (1999) Scanning electron microscopic studies on the route of neutrophil extravasation in the mouse after exposure to the chemotactic peptide $N$-formyl-methionyl-leucylphenylalanine (fMLP). Arch Histol Cytol 62(3):253-260. https ://doi.org/10.1679/aohc.62.253
123. Carman CV, Springer TA (2004) A transmigratory cup in leukocyte diapedesis both through individual vascular endothelial cells and between them. J Cell Biol 167(2):377-388. https://doi. org/10.1083/jcb.200404129

124. Phillipson M, Kaur J, Colarusso P, Ballantyne CM, Kubes P (2008) Endothelial domes encapsulate adherent neutrophils and minimize increases in vascular permeability in paracellular and transcellular emigration. PLoS ONE 3(2):e1649. https://doi. org/10.1371/journal.pone.0001649

125. Zarbock A, Singbartl K, Ley K (2006) Complete reversal of acid-induced acute lung injury by blocking of platelet-neutrophil aggregation. J Clin Investig 116(12):3211-3219. https://doi. org/10.1172/JCI29499

126. Schenkel AR, Chew TW, Chlipala E, Harbord MW, Muller WA (2006) Different susceptibilities of PECAM-deficient mouse strains to spontaneous idiopathic pneumonitis. Exp Mol Pathol 81(1):23-30. https://doi.org/10.1016/j.yexmp.2005.11.007

127. Duncan GS, Andrew DP, Takimoto H, Kaufman SA, Yoshida H, Spellberg J, de la Pompa JL, Elia A, Wakeham A, Karan-Tamir B, Muller WA, Senaldi G, Zukowski MM, Mak TW (1999) Genetic evidence for functional redundancy of platelet/endothelial cell adhesion molecule-1 (PECAM-1): CD31-deficient mice reveal PECAM-1-dependent and PECAM-1-independent functions. J Immunol 162(5):3022-3030

128. Tasaka S, Qin L, Saijo A, Albelda SM, DeLisser HM, Doerschuk CM (2003) Platelet endothelial cell adhesion molecule-1 in neutrophil emigration during acute bacterial pneumonia in mice and rats. Am J Respir Crit Care Med 167(2):164-170. https://doi. org/10.1164/rccm.2202011

129. Ostermann G, Weber KS, Zernecke A, Schroder A, Weber C (2002) JAM-1 is a ligand of the beta(2) integrin LFA-1 involved in transendothelial migration of leukocytes. Nat Immunol 3(2):151-158. https://doi.org/10.1038/ni755

130. Lakshmi SP, Reddy AT, Naik MU, Naik UP, Reddy RC (2012) Effects of JAM-A deficiency or blocking antibodies on neutrophil migration and lung injury in a murine model of ALI. Am J Physiol Lung Cell Mol Physiol 303(9):L758-766. https://doi. org/10.1152/ajplung.00107.2012

131. Chavakis T, Keiper T, Matz-Westphal R, Hersemeyer K, Sachs UJ, Nawroth PP, Preissner KT, Santoso S (2004) The junctional adhesion molecule-C promotes neutrophil transendothelial migration in vitro and in vivo. J Biol Chem 279(53):5560255608. https://doi.org/10.1074/jbc.M404676200

132. Aurrand-Lions M, Lamagna C, Dangerfield JP, Wang S, Herrera P, Nourshargh S, Imhof BA (2005) Junctional adhesion molecule-C regulates the early influx of leukocytes into tissues during inflammation. J Immunol 174(10):6406-6415. https://doi. org/10.4049/jimmunol.174.10.6406

133. Mamdouh Z, Chen X, Pierini LM, Maxfield FR, Muller WA (2003) Targeted recycling of PECAM from endothelial surface-connected compartments during diapedesis. Nature 421(6924):748-753. https://doi.org/10.1038/nature01300

134. Muller WA, Weigl SA, Deng X, Phillips DM (1993) PECAM-1 is required for transendothelial migration of leukocytes. J Exp Med 178(2):449-460. https://doi.org/10.1084/jem.178.2.449

135. Huang AJ, Manning JE, Bandak TM, Ratau MC, Hanser KR, Silverstein SC (1993) Endothelial cell cytosolic free calcium regulates neutrophil migration across monolayers of endothelial cells. J Cell Biol 120(6):1371-1380. https://doi.org/10.1083/ jcb.120.6.1371

136. Muller WA (2016) Transendothelial migration: unifying principles from the endothelial perspective. Immunol Rev 273(1):6175. https://doi.org/10.1111/imr.12443

137. Weber EW, Han F, Tauseef M, Birnbaumer L, Mehta D, Muller WA (2015) TRPC6 is the endothelial calcium channel that regulates leukocyte transendothelial migration during the 
inflammatory response. J Exp Med 212(11):1883-1899. https:// doi.org/10.1084/jem.20150353

138. Watson RL, Buck J, Levin LR, Winger RC, Wang J, Arase H, Muller WA (2015) Endothelial CD99 signals through soluble adenylyl cyclase and PKA to regulate leukocyte transendothelial migration. J Exp Med 212(7):1021-1041. https://doi. org $/ 10.1084 /$ jem. 20150354

139. Lou O, Alcaide P, Luscinskas FW, Muller WA (2007) CD99 is a key mediator of the transendothelial migration of neutrophils. J Immunol 178(2):1136-1143. https://doi.org/10.4049/jimmu nol.178.2.1136

140. Wang S, Voisin MB, Larbi KY, Dangerfield J, Scheiermann C, Tran M, Maxwell PH, Sorokin L, Nourshargh S (2006) Venular basement membranes contain specific matrix protein low expression regions that act as exit points for emigrating neutrophils. $\mathbf{J}$ Exp Med 203(6):1519-1532. https://doi.org/10.1084/jem.20051 210

141. Proebstl D, Voisin MB, Woodfin A, Whiteford J, D'Acquisto F, Jones GE, Rowe D, Nourshargh S (2012) Pericytes support neutrophil subendothelial cell crawling and breaching of venular walls in vivo. J Exp Med 209(6):1219-1234. https://doi. org/10.1084/jem.20111622

142. Pellowe AS, Sauler M, Hou Y, Merola J, Liu R, Calderon B, Lauridsen HM, Harris MR, Leng L, Zhang Y, Tilstam PV, Pober JS, Bucala R, Lee PJ, Gonzalez AL (2019) Endothelial cell-secreted MIF reduces pericyte contractility and enhances neutrophil extravasation. FASEB J 33(2):2171-2186. https://doi. org/10.1096/fj.201800480R

143. Lampugnani MG, Dejana E, Giampietro C (2018) Vascular endothelial (VE)-cadherin, endothelial adherens junctions, and vascular disease. Cold Spring Harb Perspect. https://doi. org/10.1101/cshperspect.a029322

144. Vestweber D, Winderlich M, Cagna G, Nottebaum AF (2009) Cell adhesion dynamics at endothelial junctions: VE-cadherin as a major player. Trends Cell Biol 19(1):8-15. https://doi. org/10.1016/j.tcb.2008.10.001

145. Alcaide P, Newton G, Auerbach S, Sehrawat S, Mayadas TN, Golan DE, Yacono P, Vincent P, Kowalczyk A, Luscinskas FW (2008) p120-Catenin regulates leukocyte transmigration through an effect on VE-cadherin phosphorylation. Blood 112(7):2770 2779. https://doi.org/10.1182/blood-2008-03-147181

146. Allingham MJ, van Buul JD, Burridge K (2007) ICAM-1-mediated, Src- and Pyk2-dependent vascular endothelial cadherin tyrosine phosphorylation is required for leukocyte transendothelial migration. J Immunol 179(6):4053-4064. https://doi. org/10.4049/jimmunol.179.6.4053

147. Wessel F, Winderlich M, Holm M, Frye M, Rivera-Galdos R, Vockel M, Linnepe R, Ipe U, Stadtmann A, Zarbock A, Nottebaum AF, Vestweber D (2014) Leukocyte extravasation and vascular permeability are each controlled in vivo by different tyrosine residues of VE-cadherin. Nat Immunol 15(3):223-230. https://doi.org/10.1038/ni.2824

148. Broermann A, Winderlich M, Block H, Frye M, Rossaint J, Zarbock A, Cagna G, Linnepe R, Schulte D, Nottebaum AF, Vestweber D (2011) Dissociation of VE-PTP from VE-cadherin is required for leukocyte extravasation and for VEGF-induced vascular permeability in vivo. J Exp Med 208(12):2393-2401. https://doi.org/10.1084/jem.20110525

149. Schulte D, Kuppers V, Dartsch N, Broermann A, Li H, Zarbock A, Kamenyeva O, Kiefer F, Khandoga A, Massberg S, Vestweber D (2011) Stabilizing the VE-cadherin-catenin complex blocks leukocyte extravasation and vascular permeability. EMBO J 30(20):4157-4170. https://doi.org/10.1038/emboj.2011.304

150. Tosi MF, Hamedani A, Brosovich J, Alpert SE (1994) ICAM1-independent, CD18-dependent adhesion between neutrophils and human airway epithelial cells exposed in vitro to ozone. $\mathrm{J}$ Immunol 152(4):1935-1942

151. Liu L, Mul FP, Lutter R, Roos D, Knol EF (1996) Transmigration of human neutrophils across airway epithelial cell monolayers is preferentially in the physiologic basolateral-to-apical direction. Am J Respir Cell Mol Biol 15(6):771-780. https://doi. org/10.1165/ajrcmb.15.6.8969272

152. Jagels MA, Daffern PJ, Zuraw BL, Hugli TE (1999) Mechanisms and regulation of polymorphonuclear leukocyte and eosinophil adherence to human airway epithelial cells. Am J Respir Cell Mol Biol 21(3):418-427. https://doi.org/10.1165/ajrcmb.21.3.3478

153. Herbert JA, Deng Y, Hardelid P, Robinson E, Ren L, Moulding D, Smyth RL, Smith CM (2020) Beta2-integrin LFA1 mediates airway damage following neutrophil transepithelial migration during respiratory syncytial virus infection. Eur Respir J. https ://doi.org/10.1183/13993003.02216-2019

154. Hellewell PG, Young SK, Henson PM, Worthen GS (1994) Disparate role of the beta 2-integrin CD18 in the local accumulation of neutrophils in pulmonary and cutaneous inflammation in the rabbit. Am J Respir Cell Mol Biol 10(4):391-398. https://doi. org/10.1165/ajrcmb.10.4.7510985

155. Katayama Y, Hidalgo A, Chang J, Peired A, Frenette PS (2005) CD44 is a physiological E-selectin ligand on neutrophils. J Exp Med 201(8):1183-1189. https://doi.org/10.1084/jem.20042014

156. Khan AI, Kerfoot SM, Heit B, Liu L, Andonegui G, Ruffell B, Johnson P, Kubes P (2004) Role of CD44 and hyaluronan in neutrophil recruitment. J Immunol 173(12):7594-7601. https:// doi.org/10.4049/jimmunol.173.12.7594

157. Wang Q, Teder P, Judd NP, Noble PW, Doerschuk CM (2002) CD44 deficiency leads to enhanced neutrophil migration and lung injury in Escherichia coli pneumonia in mice. Am J Pathol 161(6):2219-2228. https://doi.org/10.1016/S0002 -9440(10)64498-7

158. van der Windt GJ, Hoogendijk AJ, de Vos AF, Kerver ME, Florquin S, van der Poll T (2011) The role of CD44 in the acute and resolution phase of the host response during pneumococcal pneumonia. Lab Investig 91(4):588-597. https://doi.org/10.1038/ labinvest.2010.206

159. van der Windt GJ, Schouten M, Zeerleder S, Florquin S, van der Poll T (2011) CD44 is protective during hyperoxia-induced lung injury. Am J Respir Cell Mol Biol 44(3):377-383. https://doi. org/10.1165/rcmb.2010-0158OC

160. Liu Y, Merlin D, Burst SL, Pochet M, Madara JL, Parkos CA (2001) The role of CD47 in neutrophil transmigration. Increased rate of migration correlates with increased cell surface expression of CD47. J Biol Chem 276(43):40156-40166. https://doi. org/10.1074/jbc.M104138200

161. Liu Y, Buhring HJ, Zen K, Burst SL, Schnell FJ, Williams IR, Parkos CA (2002) Signal regulatory protein (SIRPalpha), a cellular ligand for CD47, regulates neutrophil transmigration. J Biol Chem 277(12):10028-10036. https://doi.org/10.1074/jbc.M1097 20200

162. Azcutia V, Kelm M, Luissint AC, Boerner K, Flemming S, Quiros M, Newton G, Nusrat A, Luscinskas FW, Parkos CA (2020) Neutrophil expressed CD47 regulates CD11b/CD18-dependent neutrophil transepithelial migration in the intestine in vivo. Mucosal Immunol. https://doi.org/10.1038/s41385-020-0316-4

163. Klesney-Tait J, Keck K, Li X, Gilfillan S, Otero K, Baruah S, Meyerholz DK, Varga SM, Knudson CJ, Moninger TO, Moreland J, Zabner J, Colonna M (2013) Transepithelial migration of neutrophils into the lung requires TREM-1. J Clin Investig 123(1):138-149. https://doi.org/10.1172/JCI64181

164. Baruah S, Murthy S, Keck K, Galvan I, Prichard A, Allen LH, Farrelly M, Klesney-Tait J (2019) TREM-1 regulates neutrophil chemotaxis by promoting NOX-dependent superoxide 
production. J Leukoc Biol 105(6):1195-1207. https://doi. org/10.1002/JLB.3VMA0918-375R

165. Woo CH, Yoo MH, You HJ, Cho SH, Mun YC, Seong CM, Kim JH (2003) Transepithelial migration of neutrophils in response to leukotriene B4 is mediated by a reactive oxygen species-extracellular signal-regulated kinase-linked cascade. J Immunol 170(12):6273-6279. https://doi.org/10.4049/jimmu nol.170.12.6273

166. Weber DA, Sumagin R, McCall IC, Leoni G, Neumann PA, Andargachew R, Brazil JC, Medina-Contreras O, Denning TL, Nusrat A, Parkos CA (2014) Neutrophil-derived JAML inhibits repair of intestinal epithelial injury during acute inflammation. Mucosal Immunol 7(5):1221-1232. https://doi.org/10.1038/ mi.2014.12

167. Bednarczyk M, Stege H, Grabbe S, Bros M (2020) Beta2 integrins-multi-functional leukocyte receptors in health and disease. Int J Mol Sci. https://doi.org/10.3390/ijms21041402

168. LaFoya B, Munroe JA, Miyamoto A, Detweiler MA, Crow JJ, Gazdik T, Albig AR (2018) Beyond the matrix: the many nonECM ligands for integrins. Int J Mol Sci. https://doi.org/10.3390/ ijms19020449

169. Zen K, Liu Y, Cairo D, Parkos CA (2002) CD11b/CD18-dependent interactions of neutrophils with intestinal epithelium are mediated by fucosylated proteoglycans. J Immunol 169(9):5270 5278. https://doi.org/10.4049/jimmunol.169.9.5270

170. Brazil JC, Parkos CA (2016) Pathobiology of neutrophil-epithelial interactions. Immunol Rev 273(1):94-111. https://doi. org/10.1111/imr.12446

171. Pilette C, Colinet B, Kiss R, Andre S, Kaltner H, Gabius HJ, Delos M, Vaerman JP, Decramer M, Sibille Y (2007) Increased galectin-3 expression and intra-epithelial neutrophils in small airways in severe COPD. Eur Respir J 29(5):914-922. https:// doi.org/10.1183/09031936.00073005

172. Steichen AL, Simonson TJ, Salmon SL, Metzger DW, Mishra BB, Sharma J (2015) Alarmin function of galectin-9 in murine respiratory tularemia. PLoS ONE 10(4):e0123573. https://doi. org/10.1371/journal.pone.0123573

173. Zen K, Cui LB, Zhang CY, Liu Y (2007) Critical role of mac-1 sialyl lewis $\mathrm{x}$ moieties in regulating neutrophil degranulation and transmigration. J Mol Biol 374(1):54-63. https://doi. org/10.1016/j.jmb.2007.09.014

174. Martin-Padura I, Lostaglio S, Schneemann M, Williams L, Romano M, Fruscella P, Panzeri C, Stoppacciaro A, Ruco L, Villa A, Simmons D, Dejana E (1998) Junctional adhesion molecule, a novel member of the immunoglobulin superfamily that distributes at intercellular junctions and modulates monocyte transmigration. J Cell Biol 142(1):117-127. https://doi. org/10.1083/jcb.142.1.117

175. Herold S, von Wulffen W, Steinmueller M, Pleschka S, Kuziel WA, Mack M, Srivastava M, Seeger W, Maus UA, Lohmeyer J (2006) Alveolar epithelial cells direct monocyte transepithelial migration upon influenza virus infection: impact of chemokines and adhesion molecules. J Immunol 177(3):1817-1824. https:// doi.org/10.4049/jimmunol.177.3.1817

176. Morton PE, Hicks A, Ortiz-Zapater E, Raghavan S, Pike R, Noble A, Woodfin A, Jenkins G, Rayner E, Santis G, Parsons M (2016) TNFalpha promotes CAR-dependent migration of leukocytes across epithelial monolayers. Sci Rep 6:26321. https://doi. org/10.1038/srep26321

177. Raschperger E, Engstrom U, Pettersson RF, Fuxe J (2004) CLMP, a novel member of the CTX family and a new component of epithelial tight junctions. J Biol Chem 279(1):796-804. https:// doi.org/10.1074/jbc.M308249200

178. Kast JI, Wanke K, Soyka MB, Wawrzyniak P, Akdis D, Kingo K, Rebane A, Akdis CA (2012) The broad spectrum of interepithelial junctions in skin and lung. J Allergy Clin Immunol 130(2):544-547 e544. https://doi.org/10.1016/j.jaci.2012.04.044

179. Flemming S, Luissint AC, Nusrat A, Parkos CA (2018) Analysis of leukocyte transepithelial migration using an in vivo murine colonic loop model. JCI Insight. https://doi.org/10.1172/jci.insig ht. 99722

180. Luissint AC, Williams HC, Kim W, Flemming S, Azcutia V, Hilgarth RS, Leary MNO, Denning TL, Nusrat A, Parkos CA (2019) Macrophage-dependent neutrophil recruitment is impaired under conditions of increased intestinal permeability in JAMA-deficient mice. Mucosal Immunol 12(3):668-678. https://doi. org/10.1038/s41385-019-0143-7

181. Zen K, Babbin BA, Liu Y, Whelan JB, Nusrat A, Parkos CA (2004) JAM-C is a component of desmosomes and a ligand for CD11b/CD18-mediated neutrophil transepithelial migration. Mol Biol Cell 15(8):3926-3937. https://doi.org/10.1091/mbc. e04-04-0317

182. Zen K, Liu Y, McCall IC, Wu T, Lee W, Babbin BA, Nusrat A, Parkos CA (2005) Neutrophil migration across tight junctions is mediated by adhesive interactions between epithelial coxsackie and adenovirus receptor and a junctional adhesion molecule-like protein on neutrophils. Mol Biol Cell 16(6):2694-2703. https:// doi.org/10.1091/mbc.e05-01-0036

183. Chavakis T, Bierhaus A, Al-Fakhri N, Schneider D, Witte S, Linn T, Nagashima M, Morser J, Arnold B, Preissner KT, Nawroth PP (2003) The pattern recognition receptor (RAGE) is a counterreceptor for leukocyte integrins: a novel pathway for inflammatory cell recruitment. J Exp Med 198(10):1507-1515. https://doi. org/10.1084/jem.20030800

184. Zen K, Chen CX, Chen YT, Wilton R, Liu Y (2007) Receptor for advanced glycation endproducts mediates neutrophil migration across intestinal epithelium. J Immunol 178(4):2483-2490. https ://doi.org/10.4049/jimmunol.178.4.2483

185. Demling N, Ehrhardt C, Kasper M, Laue M, Knels L, Rieber EP (2006) Promotion of cell adherence and spreading: a novel function of RAGE, the highly selective differentiation marker of human alveolar epithelial type I cells. Cell Tissue Res 323(3):475-488. https://doi.org/10.1007/s00441-005-0069-0

186. Shirasawa M, Fujiwara N, Hirabayashi S, Ohno H, Iida J, Makita K, Hata Y (2004) Receptor for advanced glycation end-products is a marker of type I lung alveolar cells. Genes Cells 9(2):165174. https://doi.org/10.1111/j.1356-9597.2004.00712.x

187. Blondonnet R, Audard J, Belville C, Clairefond G, Lutz J, Bouvier D, Roszyk L, Gross C, Lavergne M, Fournet M, Blanchon L, Vachias C, Damon-Soubeyrand C, Sapin V, Constantin JM, Jabaudon M (2017) RAGE inhibition reduces acute lung injury in mice. Sci Rep 7(1):7208. https://doi.org/10.1038/s41598-01707638-2

188. Wang H, Wang T, Yuan Z, Cao Y, Zhou Y, He J, Shen Y, Zeng N, Dai L, Wen F, Chen L (2018) Role of receptor for advanced glycation end products in regulating lung fluid balance in lipopolysaccharide-induced acute lung injury and infection-related acute respiratory distress syndrome. Shock 50(4):472-482. https://doi. org/10.1097/SHK.0000000000001032

189. Sambamurthy N, Leme AS, Oury TD, Shapiro SD (2015) The receptor for advanced glycation end products (RAGE) contributes to the progression of emphysema in mice. PLoS ONE 10(3):e0118979. https://doi.org/10.1371/journal.pone.0118979

190. Sumagin R, Robin AZ, Nusrat A, Parkos CA (2014) Transmigrated neutrophils in the intestinal lumen engage ICAM-1 to regulate the epithelial barrier and neutrophil recruitment. Mucosal Immunol 7(4):905-915. https://doi.org/10.1038/mi.2013.106

191. Brazil JC, Lee WY, Kolegraff KN, Nusrat A, Parkos CA, Louis NA (2010) Neutrophil migration across intestinal epithelium: evidence for a role of CD44 in regulating detachment of migrating 
cells from the luminal surface. J Immunol 185(11):7026-7036. https://doi.org/10.4049/jimmunol.1001293

192. Brazil JC, Liu R, Sumagin R, Kolegraff KN, Nusrat A, Cummings RD, Parkos CA, Louis NA (2013) alpha3/4 Fucosyltransferase 3-dependent synthesis of Sialyl Lewis A on CD44 variant containing exon 6 mediates polymorphonuclear leukocyte detachment from intestinal epithelium during transepithelial migration. J Immunol 191(9):4804-4817. https://doi. org/10.4049/jimmunol.1301307

193. Lawrence DW, Bruyninckx WJ, Louis NA, Lublin DM, Stahl GL, Parkos CA, Colgan SP (2003) Antiadhesive role of apical decayaccelerating factor (CD55) in human neutrophil transmigration across mucosal epithelia. J Exp Med 198(7):999-1010. https:// doi.org/10.1084/jem.20030380

194. Lin WC, Gowdy KM, Madenspacher JH, Zemans RL, Yamamoto K, Lyons-Cohen M, Nakano H, Janardhan K, Williams CJ, Cook DN, Mizgerd JP, Fessler MB (2020) Epithelial membrane protein 2 governs transepithelial migration of neutrophils into the airspace. J Clin Investig 130(1):157-170. https://doi.org/10.1172/ JCI127144

195. Wadehra M, Iyer R, Goodglick L, Braun J (2002) The tetraspan protein epithelial membrane protein-2 interacts with beta1 integrins and regulates adhesion. J Biol Chem 277(43):41094-41100. https://doi.org/10.1074/jbc.M206868200

196. Wadehra M, Su H, Gordon LK, Goodglick L, Braun J (2003) The tetraspan protein EMP2 increases surface expression of class I major histocompatibility complex proteins and susceptibility to CTL-mediated cell death. Clin Immunol 107(2):129-136. https ://doi.org/10.1016/s1521-6616(03)00048-2

197. Wadehra M, Goodglick L, Braun J (2004) The tetraspan protein EMP2 modulates the surface expression of caveolins and glycosylphosphatidyl inositol-linked proteins. Mol Biol Cell 15(5):2073-2083. https://doi.org/10.1091/mbc.e03-07-0488

198. Dahlin K, Mager EM, Allen L, Tigue Z, Goodglick L, Wadehra M, Dobbs L (2004) Identification of genes differentially expressed in rat alveolar type I cells. Am J Respir Cell Mol Biol 31(3):309-316. https://doi.org/10.1165/rcmb.2003-0423OC

199. Koh AY, Priebe GP, Ray C, Van Rooijen N, Pier GB (2009) Inescapable need for neutrophils as mediators of cellular innate immunity to acute Pseudomonas aeruginosa pneumonia. Infect Immun 77(12):5300-5310. https://doi.org/10.1128/IAI.00501-09

200. Madenspacher JH, Azzam KM, Gowdy KM, Malcolm KC, Nick JA, Dixon D, Aloor JJ, Draper DW, Guardiola JJ, Shatz M, Menendez D, Lowe J, Lu J, Bushel P, Li L, Merrick BA, Resnick MA, Fessler MB (2013) p53 Integrates host defense and cell fate during bacterial pneumonia. J Exp Med 210(5):891-904. https:// doi.org/10.1084/jem.20121674

201. Draper DW, Madenspacher JH, Dixon D, King DH, Remaley AT, Fessler MB (2010) ATP-binding cassette transporter G1 deficiency dysregulates host defense in the lung. Am J Respir Crit Care Med 182(3):404-412. https://doi.org/10.1164/rccm.20091 $0-1580 \mathrm{OC}$

202. Penaloza HF, Nieto PA, Munoz-Durango N, Salazar-Echegarai FJ, Torres J, Parga MJ, Alvarez-Lobos M, Riedel CA, Kalergis AM, Bueno SM (2015) Interleukin-10 plays a key role in the modulation of neutrophils recruitment and lung inflammation during infection by Streptococcus pneumoniae. Immunology 146(1):100-112. https://doi.org/10.1111/imm.12486

203. Li Y, Jia Y, Pichavant M, Loison F, Sarraj B, Kasorn A, You J, Robson BE, Umetsu DT, Mizgerd JP, Ye K, Luo HR (2009) Targeted deletion of tumor suppressor PTEN augments neutrophil function and enhances host defense in neutropenia-associated pneumonia. Blood 113(20):4930-4941. https://doi.org/10.1182/ blood-2008-06-161414

204. Schabbauer G, Matt U, Gunzl P, Warszawska J, Furtner T, Hainzl E, Elbau I, Mesteri I, Doninger B, Binder BR, Knapp S (2010)
Myeloid PTEN promotes inflammation but impairs bactericidal activities during murine pneumococcal pneumonia. J Immunol 185(1):468-476. https://doi.org/10.4049/jimmunol.0902221

205. Walker TS, Tomlin KL, Worthen GS, Poch KR, Lieber JG, Saavedra MT, Fessler MB, Malcolm KC, Vasil ML, Nick JA (2005) Enhanced Pseudomonas aeruginosa biofilm development mediated by human neutrophils. Infect Immun 73(6):3693-3701. https://doi.org/10.1128/IAI.73.6.3693-3701.2005

206. Dunn JLM, Kartchner LB, Stepp WH, Glenn LI, Malfitano MM, Jones SW, Doerschuk CM, Maile R, Cairns BA (2018) Blocking CXCL1-dependent neutrophil recruitment prevents immune damage and reduces pulmonary bacterial infection after inhalation injury. Am J Physiol Lung Cell Mol Physiol 314(5):L822_ L834. https://doi.org/10.1152/ajplung.00272.2017

207. Galani IE, Andreakos E (2015) Neutrophils in viral infections: current concepts and caveats. J Leukoc Biol 98(4):557-564. https ://doi.org/10.1189/jlb.4VMR1114-555R

208. Kulkarni U, Zemans RL, Smith CA, Wood SC, Deng JC, Goldstein DR (2019) Excessive neutrophil levels in the lung underlie the age-associated increase in influenza mortality. Mucosal Immunol 12(2):545-554. https://doi.org/10.1038/s4138 5-018-0115-3

209. Barnes BJ, Adrover JM, Baxter-Stoltzfus A, Borczuk A, CoolsLartigue J, Crawford JM, Dassler-Plenker J, Guerci P, Huynh C, Knight JS, Loda M, Looney MR, McAllister F, Rayes R, Renaud S, Rousseau S, Salvatore S, Schwartz RE, Spicer JD, Yost CC, Weber A, Zuo Y, Egeblad M (2020) Targeting potential drivers of COVID-19: neutrophil extracellular traps. J Exp Med. https:// doi.org/10.1084/jem.20200652

210. Zemans RL, Briones N, Campbell M, McClendon J, Young SK, Suzuki T, Yang IV, De Langhe S, Reynolds SD, Mason RJ, Kahn M, Henson PM, Colgan SP, Downey GP (2011) Neutrophil transmigration triggers repair of the lung epithelium via beta-catenin signaling. Proc Natl Acad Sci USA 108(38):15990-15995. https ://doi.org/10.1073/pnas.1110144108

211. Paris AJ, Liu Y, Mei J, Dai N, Guo L, Spruce LA, Hudock KM, Brenner JS, Zacharias WJ, Mei HD, Slamowitz AR, Bhamidipati K, Beers MF, Seeholzer SH, Morrisey EE, Worthen GS (2016) Neutrophils promote alveolar epithelial regeneration by enhancing type II pneumocyte proliferation in a model of acidinduced acute lung injury. Am J Physiol Lung Cell Mol Physiol 311(6):L1062-L1075. https://doi.org/10.1152/ajplung.00327 .2016

212. Blazquez-Prieto J, Lopez-Alonso I, Amado-Rodriguez L, Huidobro C, Gonzalez-Lopez A, Kuebler WM, Albaiceta GM (2018) Impaired lung repair during neutropenia can be reverted by matrix metalloproteinase-9. Thorax 73(4):321-330. https://doi. org/10.1136/thoraxjnl-2017-210105

213. Carlo T, Levy BD (2010) Molecular circuits of resolution in airway inflammation. Sci World J 10:1386-1399. https://doi. org/10.1100/tsw.2010.143

214. Neudecker V, Brodsky KS, Clambey ET, Schmidt EP, Packard TA, Davenport B, Standiford TJ, Weng T, Fletcher AA, Barthel L, Masterson JC, Furuta GT, Cai C, Blackburn MR, Ginde AA, Graner MW, Janssen WJ, Zemans RL, Evans CM, Burnham EL, Homann D, Moss M, Kreth S, Zacharowski K, Henson PM, Eltzschig HK (2017) Neutrophil transfer of miR-223 to lung epithelial cells dampens acute lung injury in mice. Sci Transl Med. https://doi.org/10.1126/scitranslmed.aah5360

215. Ariel A, Fredman G, Sun YP, Kantarci A, Van Dyke TE, Luster AD, Serhan CN (2006) Apoptotic neutrophils and T cells sequester chemokines during immune response resolution through modulation of CCR5 expression. Nat Immunol 7(11):1209-1216. https://doi.org/10.1038/ni1392

216. Huynh ML, Fadok VA, Henson PM (2002) Phosphatidylserinedependent ingestion of apoptotic cells promotes TGF-beta1 
secretion and the resolution of inflammation. J Clin Investig 109(1):41-50. https://doi.org/10.1172/JCI11638

217. Tate MD, Deng YM, Jones JE, Anderson GP, Brooks AG, Reading PC (2009) Neutrophils ameliorate lung injury and the development of severe disease during influenza infection. J Immunol 183(11):7441-7450. https://doi.org/10.4049/jimmu nol.0902497

218. Sapey E, Stockley JA, Greenwood H, Ahmad A, Bayley D, Lord JM, Insall RH, Stockley RA (2011) Behavioral and structural differences in migrating peripheral neutrophils from patients with chronic obstructive pulmonary disease. Am J Respir Crit Care Med 183(9):1176-1186. https://doi.org/10.1164/rccm.20100 $8-1285 \mathrm{OC}$

219. Hughes MJ, Sapey E, Stockley R (2019) Neutrophil phenotypes in chronic lung disease. Expert Rev Respir Med 13(10):951-967. https://doi.org/10.1080/17476348.2019.1654377

220. Watz H, Bock D, Meyer M, Schierhorn K, Vollhardt K, Woischwill C, Pedersen F, Kirsten A, Beeh KM, Meyer-Sabellek W, Magnussen H, Beier J (2013) Inhaled pan-selectin antagonist Bimosiamose attenuates airway inflammation in COPD. Pulm Pharmacol Ther 26(2):265-270. https://doi.org/10.1016/j. pupt.2012.12.003

221. Kirsten A, Watz H, Kretschmar G, Pedersen F, Bock D, MeyerSabellek W, Magnussen H (2011) Efficacy of the pan-selectin antagonist Bimosiamose on ozone-induced airway inflammation in healthy subjects-a double blind, randomized, placebocontrolled, cross-over clinical trial. Pulm Pharmacol Ther 24(5):555-558. https://doi.org/10.1016/j.pupt.2011.04.029

222. Seminara NM, Gelfand JM (2010) Assessing long-term drug safety: lessons (re) learned from raptiva. Semin Cutan Med Surg 29(1):16-19. https://doi.org/10.1016/j.sder.2010.01.001

223. Wichert S, Juliusson G, Johansson A, Sonesson E, Teige I, Wickenberg AT, Frendeus B, Korsgren M, Hansson M (2017) A single-arm, open-label, phase 2 clinical trial evaluating disease response following treatment with BI-505, a human anti-intercellular adhesion molecule-1 monoclonal antibody, in patients with smoldering multiple myeloma. PLoS ONE 12(2):e0171205. https ://doi.org/10.1371/journal.pone.0171205

224. Yacyshyn BR, Chey WY, Goff J, Salzberg B, Baerg R, Buchman AL, Tami J, Yu R, Gibiansky E, Shanahan WR, Investigators IC (2002) Double blind, placebo controlled trial of the remission inducing and steroid sparing properties of an ICAM-1 antisense oligodeoxynucleotide, alicaforsen (ISIS 2302), in active steroid dependent Crohn's disease. Gut 51(1):30-36. https://doi. org/10.1136/gut.51.1.30

225. Yacyshyn B, Chey WY, Wedel MK, Yu RZ, Paul D, Chuang E (2007) A randomized, double-masked, placebo-controlled study of alicaforsen, an antisense inhibitor of intercellular adhesion molecule 1 , for the treatment of subjects with active Crohn's disease. Clin Gastroenterol Hepatol 5(2):215-220. https://doi. org/10.1016/j.cgh.2006.11.001

226. Reinisch W, Hung K, Hassan-Zahraee M, Cataldi F (2018) Targeting endothelial ligands: ICAM-1/alicaforsen, MAdCAM-1. J Crohns Colitis 12(suppl_2):S669-S677. https://doi.org/10.1093/ ecco-jcc/jjy059

227. Scarozza P, Schmitt H, Monteleone G, Neurath MF, Atreya R (2019) Oligonucleotides-a novel promising therapeutic option for IBD. Front Pharmacol 10:314. https://doi.org/10.3389/fphar .2019 .00314

228. Atlantic-Pharmaceuticals (2020) Efficacy of alicaforsen in pouchitis patients who have failed to respond to at least one course of antibiotics. ClinicalTrials.gov. NCT02525523

229. Klausz K, Cieker M, Kellner C, Rosner T, Otte A, Krohn S, Lux A, Nimmerjahn F, Valerius T, Gramatzki M, Peipp M (2020) Fc-engineering significantly improves the recruitment of immune effector cells by anti-ICAM-1 antibody MSH-TP15 for myeloma therapy. Haematologica. https://doi.org/10.3324/haema tol.2020.251371

230. Leaker BR, Barnes PJ, O'Connor B (2013) Inhibition of LPSinduced airway neutrophilic inflammation in healthy volunteers with an oral CXCR2 antagonist. Respir Res 14:137. https://doi. org/10.1186/1465-9921-14-137

231. Kirsten AM, Forster K, Radeczky E, Linnhoff A, Balint B, Watz H, Wray H, Salkeld L, Cullberg M, Larsson B (2015) The safety and tolerability of oral AZD5069, a selective CXCR2 antagonist, in patients with moderate-to-severe COPD. Pulm Pharmacol Ther 31:36-41. https://doi.org/10.1016/j.pupt.2015.02.001

232. De Soyza A, Pavord I, Elborn JS, Smith D, Wray H, Puu M, Larsson B, Stockley R (2015) A randomised, placebo-controlled study of the CXCR2 antagonist AZD5069 in bronchiectasis. Eur Respir J 46(4):1021-1032. https://doi.org/10.1183/13993 003.00148-2015

233. O’Byrne PM, Metev H, Puu M, Richter K, Keen C, Uddin M, Larsson B, Cullberg M, Nair P (2016) Efficacy and safety of a CXCR2 antagonist, AZD5069, in patients with uncontrolled persistent asthma: a randomised, double-blind, placebo-controlled trial. Lancet Respir Med 4(10):797-806. https://doi.org/10.1016/ S2213-2600(16)30227-2

234. Watz H, Uddin M, Pedersen F, Kirsten A, Goldmann T, Stellmacher F, Groth E, Larsson B, Bottcher G, Malmgren A, Kraan M, Rabe KF (2017) Effects of the CXCR2 antagonist AZD5069 on lung neutrophil recruitment in asthma. Pulm Pharmacol Ther 45:121-123. https://doi.org/10.1016/j.pupt.2017.05.012

235. Lazaar AL, Miller BE, Donald AC, Keeley T, Ambery C, Russell J, Watz H, Tal-Singer R, for I (2020) CXCR2 antagonist for patients with chronic obstructive pulmonary disease with chronic mucus hypersecretion: a phase $2 \mathrm{~b}$ trial. Respir Res 21(1):149. https://doi.org/10.1186/s12931-020-01401-4

236. Madan A, Chen S, Yates P, Washburn ML, Roberts G, Peat AJ, Tao Y, Parry MF, Barnum O, McClain MT, Roy-Ghanta S (2019) Efficacy and safety of danirixin (GSK1325756) co-administered with standard-of-care antiviral (oseltamivir): a phase $2 \mathrm{~b}$, global, randomized study of adults hospitalized with influenza. Open Forum Infect Dis 6(4):ofz163. https://doi.org/10.1093/ofid/ofz16 3

237. Roberts G, Chen S, Yates P, Madan A, Walker J, Washburn ML, Peat AJ, Soucie G, Kerwin E, Roy-Ghanta S (2019) Randomized, double-blind, placebo-controlled study of the safety, tolerability, and clinical effect of danirixin in adults with acute, uncomplicated influenza. Open Forum Infect Dis 6(4):ofz072. https://doi. org/10.1093/ofid/ofz072

238. Lazaar AL, Sweeney LE, MacDonald AJ, Alexis NE, Chen C, Tal-Singer R (2011) SB-656933, a novel CXCR2 selective antagonist, inhibits ex vivo neutrophil activation and ozoneinduced airway inflammation in humans. Br J Clin Pharmacol 72(2):282-293. https://doi.org/10.1111/j.1365-2125.2011.03968 .x

239. Moss RB, Mistry SJ, Konstan MW, Pilewski JM, Kerem E, TalSinger R, Lazaar AL, Investigators CF (2013) Safety and early treatment effects of the CXCR2 antagonist SB-656933 in patients with cystic fibrosis. J Cyst Fibros 12(3):241-248. https://doi. org/10.1016/j.jcf.2012.08.016

240. Rennard SI, Dale DC, Donohue JF, Kanniess F, Magnussen H, Sutherland ER, Watz H, Lu S, Stryszak P, Rosenberg E, Staudinger H (2015) CXCR2 antagonist MK-7123. A phase 2 proof-of-concept trial for chronic obstructive pulmonary disease. Am J Respir Crit Care Med 191(9):1001-1011. https:// doi.org/10.1164/rccm.201405-0992OC

241. Nair P, Gaga M, Zervas E, Alagha K, Hargreave FE, O’Byrne PM, Stryszak P, Gann L, Sadeh J, Chanez P, Study I (2012) Safety and efficacy of a CXCR2 antagonist in patients with severe asthma and sputum neutrophils: a randomized, 
placebo-controlled clinical trial. Clin Exp Allergy 42(7):10971103. https://doi.org/10.1111/j.1365-2222.2012.04014.x

242. Dorward DA, Lucas CD, Doherty MK, Chapman GB, Scholefield EJ, Conway Morris A, Felton JM, Kipari T, Humphries DC, Robb CT, Simpson AJ, Whitfield PD, Haslett C, Dhaliwal K, Rossi AG (2017) Novel role for endogenous mitochondrial formylated peptide-driven formyl peptide receptor 1 signalling in acute respiratory distress syndrome. Thorax 72(10):928-936. https://doi.org/10.1136/thoraxjnl-2017-210030

243. Leslie J, Millar BJ, Del Carpio PA, Burgoyne RA, Frost JD, Barksby BS, Luli S, Scott J, Simpson AJ, Gauldie J, Murray LA, Finch DK, Carruthers AM, Ferguson J, Sleeman MA, Rider D, Howarth R, Fox C, Oakley F, Fisher AJ, Mann DA, Borthwick LA (2020) FPR-1 is an important regulator of neutrophil recruitment and a tissue-specific driver of pulmonary fibrosis. JCI Insight. https://doi.org/10.1172/jci.insight.125937

244. Schepetkin IA, Khlebnikov AI, Kirpotina LN, Quinn MT (2016) Antagonism of human formyl peptide receptor 1 with natural compounds and their synthetic derivatives. Int Immunopharmacol 37:43-58. https://doi.org/10.1016/j.intimp.2015.08.036

245. He HQ, Ye RD (2017) The formyl peptide receptors: diversity of ligands and mechanism for recognition. Molecules. https://doi. org/10.3390/molecules22030455

246. Konstan MW, Doring G, Heltshe SL, Lands LC, Hilliard KA, Koker P, Bhattacharya S, Staab A, Hamilton A, Investigators, Coordinators of BIT (2014) A randomized double blind, placebo controlled phase 2 trial of BIIL 284 BS (an LTB4 receptor antagonist) for the treatment of lung disease in children and adults with cystic fibrosis. J Cyst Fibros 13(2):148-155. https:// doi.org/10.1016/j.jcf.2013.12.009

247. Doring G, Bragonzi A, Paroni M, Akturk FF, Cigana C, Schmidt A, Gilpin D, Heyder S, Born T, Smaczny C, Kohlhaufl M, Wagner TO, Loebinger MR, Bilton D, Tunney MM, Elborn JS, Pier GB, Konstan MW, Ulrich M (2014) BIIL 284 reduces neutrophil numbers but increases $P$. aeruginosa bacteremia and inflammation in mouse lungs. J Cyst Fibros 13(2):156-163. https://doi. org/10.1016/j.jcf.2013.10.007

248. Dunne AE, Kawamatawong T, Fenwick PS, Davies CM, Tullett H, Barnes PJ, Donnelly LE (2019) Direct inhibitory effect of the PDE4 inhibitor roflumilast on neutrophil migration in chronic obstructive pulmonary disease. Am J Respir Cell Mol Biol 60(4):445-453. https://doi.org/10.1165/rcmb.2018-0065OC

249. Fessler MB (2019) Drugging the mighty neutrophil in chronic obstructive pulmonary disease. Am J Respir Cell Mol Biol 60(4):382-383. https://doi.org/10.1165/rcmb.2018-0370ED

250. Phillips JE (2020) Inhaled phosphodiesterase 4 (PDE4) inhibitors for inflammatory respiratory diseases. Front Pharmacol 11:259. https://doi.org/10.3389/fphar.2020.00259

251. Singh D, Beeh KM, Colgan B, Kornmann O, Leaker B, Watz H, Lucci G, Geraci S, Emirova A, Govoni M, Nandeuil MA (2019) Effect of the inhaled PDE4 inhibitor CHF6001 on biomarkers of inflammation in COPD. Respir Res 20(1):180. https://doi. org/10.1186/s12931-019-1142-7

252. Singh D, Leaker B, Boyce M, Nandeuil MA, Collarini S, Mariotti F, Santoro D, Barnes PJ (2016) A novel inhaled phosphodiesterase 4 inhibitor (CHF6001) reduces the allergen challenge response in asthmatic patients. Pulm Pharmacol Ther 40:1-6. https://doi.org/10.1016/j.pupt.2016.06.011

253. Govoni M, Bassi M, Vezzoli S, Lucci G, Emirova A, Nandeuil MA, Petruzzelli S, Jellema GL, Afolabi EK, Colgan B, Leaker B, Kornmann O, Beeh KM, Watz H, Singh D (2020) Sputum and blood transcriptomics characterisation of the inhaled PDE4 inhibitor CHF6001 on top of triple therapy in patients with chronic bronchitis. Respir Res 21(1):72. https://doi.org/10.1186/ s12931-020-1329-y
254. Kim JS, Jeong JS, Kwon SH, Kim SR, Lee YC (2020) Roles of PI3K pan-inhibitors and PI3K-delta inhibitors in allergic lung inflammation: a systematic review and meta-analysis. Sci Rep 10(1):7608. https://doi.org/10.1038/s41598-020-64594-0

255. Campa CC, Silva RL, Margaria JP, Pirali T, Mattos MS, Kraemer LR, Reis DC, Grosa G, Copperi F, Dalmarco EM, LimaJunior RCP, Aprile S, Sala V, Dal Bello F, Prado DS, Alves-Filho JC, Medana C, Cassali GD, Tron GC, Teixeira MM, Ciraolo E, Russo RC, Hirsch E (2018) Inhalation of the prodrug PI3K inhibitor CL27c improves lung function in asthma and fibrosis. Nat Commun 9(1):5232. https://doi.org/10.1038/s41467-01807698-6

256. Sapey E, Greenwood H, Walton G, Mann E, Love A, Aaronson N, Insall RH, Stockley RA, Lord JM (2014) Phosphoinositide 3-kinase inhibition restores neutrophil accuracy in the elderly: toward targeted treatments for immunosenescence. Blood 123(2):239-248. https://doi.org/10.1182/blood-2013-08-519520

257. Fessler MB, Young SK, Jeyaseelan S, Lieber JG, Arndt PG, Nick JA, Worthen GS (2005) A role for hydroxy-methylglutaryl coenzyme a reductase in pulmonary inflammation and host defense. Am J Respir Crit Care Med 171(6):606-615. https:// doi.org/10.1164/rccm.200406-729OC

258. Zhang S, Rahman M, Zhang S, Qi Z, Herwald H, Thorlacius H (2011) Simvastatin regulates CXC chemokine formation in streptococcal M1 protein-induced neutrophil infiltration in the lung. Am J Physiol Lung Cell Mol Physiol 300(6):L930-939. https://doi.org/10.1152/ajplung.00422.2010

259. Grommes J, Vijayan S, Drechsler M, Hartwig H, Morgelin M, Dembinski R, Jacobs M, Koeppel TA, Binnebosel M, Weber C, Soehnlein O (2012) Simvastatin reduces endotoxin-induced acute lung injury by decreasing neutrophil recruitment and radical formation. PLoS ONE 7(6):e38917. https://doi.org/10.1371/ journal.pone. 0038917

260. Shyamsundar M, McKeown ST, O'Kane CM, Craig TR, Brown V, Thickett DR, Matthay MA, Taggart CC, Backman JT, Elborn JS, McAuley DF (2009) Simvastatin decreases lipopolysaccharide-induced pulmonary inflammation in healthy volunteers. Am J Respir Crit Care Med 179(12):1107-1114. https://doi. org/10.1164/rcem.200810-1584OC

261. Karmaus PW, Shi M, Perl S, Biancotto A, Candia J, Cheung F, Kotliarov Y, Young N, Fessler MB, Consortium CHI (2019) Effects of rosuvastatin on the immune system in healthy volunteers with normal serum cholesterol. JCI Insight. https://doi. org/10.1172/jci.insight. 131530

262. McAuley DF, Laffey JG, O'Kane CM, Perkins GD, Mullan B, Trinder TJ, Johnston P, Hopkins PA, Johnston AJ, McDowell C, McNally C, Investigators H, Irish Critical Care Trials G ( 2014) Simvastatin in the acute respiratory distress syndrome. N Engl J Med 371(18):1695-1703. https://doi.org/10.1056/NEJMoa1403 285

263. Criner GJ, Connett JE, Aaron SD, Albert RK, Bailey WC, Casaburi R, Cooper JA Jr, Curtis JL, Dransfield MT, Han MK, Make B, Marchetti N, Martinez FJ, Niewoehner DE, Scanlon PD, Sciurba FC, Scharf SM, Sin DD, Voelker H, Washko GR, Woodruff PG, Lazarus SC, Network CCR, Canadian Institutes of Health R (2014) Simvastatin for the prevention of exacerbations in moderate-to-severe COPD. N Engl J Med 370(23):2201-2210. https ://doi.org/10.1056/NEJMoa1403086

264. Calfee CS, Delucchi KL, Sinha P, Matthay MA, Hackett J, Shankar-Hari M, McDowell C, Laffey JG, O'Kane CM, McAuley DF, Irish Critical Care Trials G ( 2018) Acute respiratory distress syndrome subphenotypes and differential response to simvastatin: secondary analysis of a randomised controlled trial. Lancet Respir Med 6(9):691-698. https://doi.org/10.1016/S2213 $-2600(18) 30177-2$ 
265. Walton GM, Stockley JA, Griffiths D, Sadhra CS, Purvis T, Sapey E (2016) Repurposing treatments to enhance innate immunity. Can statins improve neutrophil functions and clinical outcomes in COPD? J Clin Med. https://doi.org/10.3390/jcm5100089

266. Lahousse L, Loth DW, Joos GF, Hofman A, Leufkens HG, Brusselle GG, Stricker BH (2013) Statins, systemic inflammation and risk of death in COPD: the Rotterdam study. Pulm Pharmacol Ther 26(2):212-217. https://doi.org/10.1016/j.pupt.2012.10.008

267. Zhang W, Zhang Y, Li CW, Jones P, Wang C, Fan Y (2017) Effect of statins on COPD: a meta-analysis of randomized controlled trials. Chest 152(6):1159-1168. https://doi.org/10.1016/j. chest.2017.08.015

268. Sapey E, Patel JM, Greenwood HL, Walton GM, Hazeldine J, Sadhra C, Parekh D, Dancer RCA, Nightingale P, Lord JM, Thickett DR (2017) Pulmonary infections in the elderly lead to impaired neutrophil targeting, which is improved by simvastatin. Am J Respir Crit Care Med 196(10):1325-1336. https://doi. org/10.1164/rccm.201704-0814OC

269. Sapey E, Patel JM, Greenwood H, Walton GM, Grudzinska F, Parekh D, Mahida RY, Dancer RCA, Lugg ST, Howells PA, Hazeldine J, Newby P, Scott A, Nightingale P, Hill AT, Thickett DR (2019) Simvastatin improves neutrophil function and clinical outcomes in pneumonia. A pilot randomized controlled clinical trial. Am J Respir Crit Care Med 200(10):1282-1293. https://doi. org/10.1164/rccm.201812-2328OC

270. Chow OA, von Kockritz-Blickwede M, Bright AT, Hensler ME, Zinkernagel AS, Cogen AL, Gallo RL, Monestier M, Wang Y, Glass CK, Nizet V (2010) Statins enhance formation of phagocyte extracellular traps. Cell Host Microbe 8(5):445-454. https ://doi.org/10.1016/j.chom.2010.10.005

271. Yamada M, Kubo H, Kobayashi S, Ishizawa K, He M, Suzuki T, Fujino N, Kunishima H, Hatta M, Nishimaki K, Aoyagi T, Tokuda K, Kitagawa M, Yano H, Tamamura H, Fujii N, Kaku M (2011) The increase in surface CXCR4 expression on lung extravascular neutrophils and its effects on neutrophils during endotoxin-induced lung injury. Cell Mol Immunol 8(4):305-314. https://doi.org/10.1038/cmi.2011.8

272. Isles HM, Herman KD, Robertson AL, Loynes CA, Prince LR, Elks PM, Renshaw SA (2019) The CXCL12/CXCR4 signaling axis retains neutrophils at inflammatory sites in zebrafish. Front Immunol 10:1784. https://doi.org/10.3389/fimmu.2019.01784

273. Hartl D, Krauss-Etschmann S, Koller B, Hordijk PL, Kuijpers TW, Hoffmann F, Hector A, Eber E, Marcos V, Bittmann I, Eickelberg O, Griese M, Roos D (2008) Infiltrated neutrophils acquire novel chemokine receptor expression and chemokine responsiveness in chronic inflammatory lung diseases. J Immunol 181(11):8053-8067. https://doi.org/10.4049/jimmu nol.181.11.8053

274. Chellappan DK, Yee LW, Xuan KY, Kunalan K, Rou LC, Jean LS, Ying LY, Wie LX, Chellian J, Mehta M, Satija S, Singh SK, Gulati M, Dureja H, Da Silva MW, Tambuwala MM, Gupta G, Paudel KR, Wadhwa R, Hansbro PM, Dua K (2020) Targeting neutrophils using novel drug delivery systems in chronic respiratory diseases. Drug Dev Res 81(4):419-436. https://doi. org/10.1002/ddr.21648

275. Seys SF, Lokwani R, Simpson JL, Bullens DMA (2019) New insights in neutrophilic asthma. Curr Opin Pulm Med 25(1):113120. https://doi.org/10.1097/MCP.0000000000000543

276. Chu D, Gao J, Wang Z (2015) Neutrophil-mediated delivery of therapeutic nanoparticles across blood vessel barrier for treatment of inflammation and infection. ACS Nano 9(12):1180011811. https://doi.org/10.1021/acsnano.5b05583

277. Giacalone VD, Margaroli C, Mall MA, Tirouvanziam R (2020) Neutrophil adaptations upon recruitment to the lung: new concepts and implications for homeostasis and disease. Int J Mol Sci. https://doi.org/10.3390/ijms21030851
278. Forrest OA, Ingersoll SA, Preininger MK, Laval J, Limoli DH, Brown MR, Lee FE, Bedi B, Sadikot RT, Goldberg JB, Tangpricha V, Gaggar A, Tirouvanziam R (2018) Frontline science: pathological conditioning of human neutrophils recruited to the airway milieu in cystic fibrosis. J Leukoc Biol 104(4):665-675. https://doi.org/10.1002/JLB.5HI1117-454RR

279. Ramamoorthy C, Sasaki SS, Su DL, Sharar SR, Harlan JM, Winn RK (1997) CD18 adhesion blockade decreases bacterial clearance and neutrophil recruitment after intrapulmonary E. coli, but not after $S$. aureus. J Leukoc Biol 61(2):167-172. https://doi. org/10.1002/jlb.61.2.167

280. Motosugi H, Quinlan WM, Bree M, Doerschuk CM (1998) Role of CD11b in focal acid-induced pneumonia and contralateral lung injury in rats. Am J Respir Crit Care Med 157(1):192-198. https://doi.org/10.1164/ajrccm.157.1.9602095

281. Mulligan MS, Wilson GP, Todd RF, Smith CW, Anderson DC, Varani J, Issekutz TB, Miyasaka M, Tamatani T et al (1993) Role of beta 1, beta 2 integrins and ICAM-1 in lung injury after deposition of $\mathrm{IgG}$ and $\mathrm{IgA}$ immune complexes. J Immunol 150(6):2407-2417

282. Sherman MP, Johnson JT, Rothlein R, Hughes BJ, Smith CW, Anderson DC (1992) Role of pulmonary phagocytes in host defense against group B streptococci in preterm versus term rabbit lung. J Infect Dis 166(4):818-826. https://doi.org/10.1093/ infdis/166.4.818

283. Keeney SE, Mathews MJ, Haque AK, Rudloff HE, Schmalstieg FC (1994) Oxygen-induced lung injury in the guinea pig proceeds through CD18-independent mechanisms. Am J Respir Crit Care Med 149(2 Pt 1):311-319. https://doi.org/10.1164/ajrcc m.149.2.7905767

284. Smith CW, Marlin SD, Rothlein R, Toman C, Anderson DC (1989) Cooperative interactions of LFA-1 and Mac-1 with intercellular adhesion molecule- 1 in facilitating adherence and transendothelial migration of human neutrophils in vitro. J Clin Investig 83(6):2008-2017. https://doi.org/10.1172/JCI114111

285. Luscinskas FW, Brock AF, Arnaout MA, Gimbrone MA Jr (1989) Endothelial-leukocyte adhesion molecule-1-dependent and leukocyte (CD11/CD18)-dependent mechanisms contribute to polymorphonuclear leukocyte adhesion to cytokine-activated human vascular endothelium. J Immunol 142(7):2257-2263

286. Diamond MS, Staunton DE, de Fougerolles AR, Stacker SA, Garcia-Aguilar J, Hibbs ML, Springer TA (1990) ICAM-1 (CD54): a counter-receptor for Mac-1 (CD11b/CD18). J Cell Biol 111(6 Pt 2):3129-3139. https://doi.org/10.1083/jcb.111.6.3129

287. Mackarel AJ, Russell KJ, Brady CS, FitzGerald MX, O'Connor CM (2000) Interleukin-8 and leukotriene-B(4), but not formylmethionyl leucylphenylalanine, stimulate CD18-independent migration of neutrophils across human pulmonary endothelial cells in vitro. Am J Respir Cell Mol Biol 23(2):154-161. https:// doi.org/10.1165/ajrcmb.23.2.3853

288. Morland CM, Morland BJ, Darbyshire PJ, Stockley RA (2000) Migration of CD18-deficient neutrophils in vitro: evidence for a CD18-independent pathway induced by IL-8. Biochim Biophys Acta 1500(1):70-76. https://doi.org/10.1016/s0925 -4439(99)00089-7

289. Schenkel AR, Chew TW, Muller WA (2004) Platelet endothelial cell adhesion molecule deficiency or blockade significantly reduces leukocyte emigration in a majority of mouse strains. $\mathbf{J}$ Immunol 173(10):6403-6408. https://doi.org/10.4049/jimmu nol.173.10.6403

290. Cooper D, Lindberg FP, Gamble JR, Brown EJ, Vadas MA (1995) Transendothelial migration of neutrophils involves integrin-associated protein (CD47). Proc Natl Acad Sci USA 92(9):3978-3982. https://doi.org/10.1073/pnas.92.9.3978

291. Stefanidakis M, Newton G, Lee WY, Parkos CA, Luscinskas FW (2008) Endothelial CD47 interaction with SIRPgamma is 
required for human T-cell transendothelial migration under shear flow conditions in vitro. Blood 112(4):1280-1289. https://doi. org/10.1182/blood-2008-01-134429

292. Yao Y, Matsushima H, Ohtola JA, Geng S, Lu R, Takashima A (2015) Neutrophil priming occurs in a sequential manner and can be visualized in living animals by monitoring IL-1beta promoter activation. J Immunol 194(3):1211-1224. https://doi. org/10.4049/jimmunol.1402018

293. Smith CW, Rothlein R, Hughes BJ, Mariscalco MM, Rudloff HE, Schmalstieg FC, Anderson DC (1988) Recognition of an endothelial determinant for CD 18-dependent human neutrophil adherence and transendothelial migration. J Clin Investig 82(5):1746-1756. https://doi.org/10.1172/JCI113788

294. Berger M, Medof ME (1987) Increased expression of complement decay-accelerating factor during activation of human neutrophils. J Clin Investig 79(1):214-220. https://doi.org/10.1172/ JCI112786

295. Tausk F, Fey M, Gigli I (1989) Endocytosis and shedding of the decay accelerating factor on human polymorphonuclear cells. $\mathbf{J}$ Immunol 143(10):3295-3302

296. Hurley BP, Sin A, McCormick BA (2008) Adhesion molecules involved in hepoxilin A3-mediated neutrophil transepithelial migration. Clin Exp Immunol 151(2):297-305. https://doi.org /10.1111/j.1365-2249.2007.03551.x

297. Mason JC, Yarwood H, Sugars K, Morgan BP, Davies KA, Haskard DO (1999) Induction of decay-accelerating factor by cytokines or the membrane-attack complex protects vascular endothelial cells against complement deposition. Blood 94(5):1673-1682

298. Mason JC, Lidington EA, Yarwood H, Lublin DM, Haskard DO (2001) Induction of endothelial cell decay-accelerating factor by vascular endothelial growth factor: a mechanism for cytoprotection against complement-mediated injury during inflammatory angiogenesis. Arthritis Rheum 44(1):138-150. https:// doi.org/10.1002/1529-0131(200101)44:1\%3c138::AID-ANR18 \%3e3.0.CO;2-G

299. Ivetic A, Hoskins Green HL, Hart SJ (2019) L-selectin: a major regulator of leukocyte adhesion. Migr Signal Front Immunol 10:1068. https://doi.org/10.3389/fimmu.2019.01068

300. Bixel MG, Petri B, Khandoga AG, Khandoga A, Wolburg-Buchholz K, Wolburg H, Marz S, Krombach F, Vestweber D (2007) A CD99-related antigen on endothelial cells mediates neutrophil but not lymphocyte extravasation in vivo. Blood 109(12):53275336. https://doi.org/10.1182/blood-2006-08-043109

301. Sundd P, Gutierrez E, Koltsova EK, Kuwano Y, Fukuda S, Pospieszalska MK, Groisman A, Ley K (2012) "Slings" enable neutrophil rolling at high shear. Nature 488(7411):399-403. https ://doi.org/10.1038/nature11248

302. Huang MT, Larbi KY, Scheiermann C, Woodfin A, Gerwin N, Haskard DO, Nourshargh S (2006) ICAM-2 mediates neutrophil transmigration in vivo: evidence for stimulus specificity and a role in PECAM-1-independent transmigration. Blood 107(12):4721-4727. https://doi.org/10.1182/blood $-2005-11-4683$

303. Halai K, Whiteford J, Ma B, Nourshargh S, Woodfin A (2014) ICAM-2 facilitates luminal interactions between neutrophils and endothelial cells in vivo. J Cell Sci 127(Pt 3):620-629. https:// doi.org/10.1242/jcs. 137463

304. Vestweber D (2007) Adhesion and signaling molecules controlling the transmigration of leukocytes through endothelium. Immunol Rev 218:178-196. https://doi.org/10.1111/j.1600065X.2007.00533.X

305. Zarbock A, Ley K, McEver RP, Hidalgo A (2011) Leukocyte ligands for endothelial selectins: specialized glycoconjugates that mediate rolling and signaling under flow. Blood 118(26):67436751. https://doi.org/10.1182/blood-2011-07-343566
306. Rivera-Nieves J, Burcin TL, Olson TS, Morris MA, McDuffie M, Cominelli F, Ley K (2006) Critical role of endothelial $\mathrm{P}$-selectin glycoprotein ligand 1 in chronic murine ileitis. J Exp Med 203(4):907-917. https://doi.org/10.1084/jem.20052 530

307. da Costa MP, Garcia-Vallejo JJ, van Thienen JV, FernandezBorja M, van Gils JM, Beckers C, Horrevoets AJ, Hordijk $\mathrm{PL}$, Zwaginga JJ (2007) P-selectin glycoprotein ligand-1 is expressed on endothelial cells and mediates monocyte adhesion to activated endothelium. Arterioscler Thromb Vasc Biol 27(5):1023-1029. https://doi.org/10.1161/ATVBA HA. 107.140442

308. Liu Y, Nusrat A, Schnell FJ, Reaves TA, Walsh S, Pochet M, Parkos CA (2000) Human junction adhesion molecule regulates tight junction resealing in epithelia. J Cell Sci $113(\mathrm{Pt}$ 13):2363-2374

309. Corada M, Chimenti S, Cera MR, Vinci M, Salio M, Fiordaliso F, De Angelis N, Villa A, Bossi M, Staszewsky LI, Vecchi A, Parazzoli D, Motoike T, Latini R, Dejana E (2005) Junctional adhesion molecule-A-deficient polymorphonuclear cells show reduced diapedesis in peritonitis and heart ischemia-reperfusion injury. Proc Natl Acad Sci USA 102(30):10634-10639. https:// doi.org/10.1073/pnas.0500147102

310. Cera MR, Fabbri M, Molendini C, Corada M, Orsenigo F, Rehberg M, Reichel CA, Krombach F, Pardi R, Dejana E (2009) JAM-A promotes neutrophil chemotaxis by controlling integrin internalization and recycling. J Cell Sci 122(Pt 2):268-277. https ://doi.org/10.1242/jcs.037127

311. Woodfin A, Voisin MB, Beyrau M, Colom B, Caille D, Diapouli FM, Nash GB, Chavakis T, Albelda SM, Rainger GE, Meda P, Imhof BA, Nourshargh S (2011) The junctional adhesion molecule JAM-C regulates polarized transendothelial migration of neutrophils in vivo. Nat Immunol 12(8):761-769. https://doi. org/10.1038/ni.2062

312. Wegmann F, Petri B, Khandoga AG, Moser C, Khandoga A, Volkery S, Li H, Nasdala I, Brandau O, Fassler R, Butz S, Krombach F, Vestweber D (2006) ESAM supports neutrophil extravasation, activation of Rho, and VEGF-induced vascular permeability. J Exp Med 203(7):1671-1677. https://doi.org/10.1084/ jem. 20060565

313. Collison KS, Parhar RS, Saleh SS, Meyer BF, Kwaasi AA, Hammami MM, Schmidt AM, Stern DM, Al-Mohanna FA (2002) RAGE-mediated neutrophil dysfunction is evoked by advanced glycation end products (AGEs). J Leukoc Biol 71(3):433-444

314. Frommhold D, Kamphues A, Hepper I, Pruenster M, Lukic IK, Socher I, Zablotskaya V, Buschmann K, Lange-Sperandio B, Schymeinsky J, Ryschich E, Poeschl J, Kupatt C, Nawroth PP, Moser M, Walzog B, Bierhaus A, Sperandio M (2010) RAGE and ICAM-1 cooperate in mediating leukocyte recruitment during acute inflammation in vivo. Blood 116(5):841-849. https:// doi.org/10.1182/blood-2009-09-244293

315. Sperandio M, Gleissner CA, Ley K (2009) Glycosylation in immune cell trafficking. Immunol Rev 230(1):97-113. https:// doi.org/10.1111/j.1600-065X.2009.00795.X

316. Wright RD, Cooper D (2014) Glycobiology of leukocyte trafficking in inflammation. Glycobiology 24(12):1242-1251. https ://doi.org/10.1093/glycob/cwu101

317. Sakarya S, Rifat S, Zhou J, Bannerman DD, Stamatos NM, Cross AS, Goldblum SE (2004) Mobilization of neutrophil sialidase activity desialylates the pulmonary vascular endothelial surface and increases resting neutrophil adhesion to and migration across the endothelium. Glycobiology 14(6):481-494. https:// doi.org/10.1093/glycob/cwh065

318. Mayfosh AJ, Baschuk N, Hulett MD (2019) Leukocyte heparanase: a double-edged sword in tumor progression. Front Oncol 9:331. https://doi.org/10.3389/fonc.2019.00331 
319. Calandra T, Roger T (2003) Macrophage migration inhibitory factor: a regulator of innate immunity. Nat Rev Immunol 3(10):791-800. https://doi.org/10.1038/nri1200

320. Kidney JC, Proud D (2000) Neutrophil transmigration across human airway epithelial monolayers: mechanisms and dependence on electrical resistance. Am J Respir Cell Mol Biol 23(3):389-395. https://doi.org/10.1165/ajrcmb.23.3.4068

321. Parkos CA, Delp C, Arnaout MA, Madara JL (1991) Neutrophil migration across a cultured intestinal epithelium. Dependence on a CD11b/CD18-mediated event and enhanced efficiency in physiological direction. J Clin Investig 88(5):1605-1612. https ://doi.org/10.1172/JCI115473

322. Balsam LB, Liang TW, Parkos CA (1998) Functional mapping of CD11b/CD18 epitopes important in neutrophil-epithelial interactions: a central role of the I domain. J Immunol 160(10):5058-5065

323. Carrigan SO, Weppler AL, Issekutz AC, Stadnyk AW (2005) Neutrophil differentiated HL-60 cells model Mac-1 (CD11b/ CD18)-independent neutrophil transepithelial migration. Immunology 115(1):108-117. https://doi.org/10.111 1/j.1365-2567.2005.02131.x

324. Blake KM, Carrigan SO, Issekutz AC, Stadnyk AW (2004) Neutrophils migrate across intestinal epithelium using beta2 integrin (CD11b/CD18)-independent mechanisms. Clin Exp Immunol 136(2):262-268. https://doi.org/10.111 1/j.1365-2249.2004.02429.x

325. Kasper M, Gunthert U, Dall P, Kayser K, Schuh D, Haroske G, Muller M (1995) Distinct expression patterns of CD44 isoforms during human lung development and in pulmonary fibrosis. Am J Respir Cell Mol Biol 13(6):648-656. https://doi.org/10.1165/ ajrcmb.13.6.7576702

326. Leir SH, Baker JE, Holgate ST, Lackie PM (2000) Increased CD44 expression in human bronchial epithelial repair after damage or plating at low cell densities. Am J Physiol Lung Cell Mol Physiol 278(6):L1129-1137. https://doi.org/10.1152/ajplu ng.2000.278.6.L1129

327. Si-Tahar M, Sitaraman S, Shibahara T, Madara JL (2001) Negative regulation of epithelium-neutrophil interactions via activation of CD44. Am J Physiol Cell Physiol 280(3):C423-432. https ://doi.org/10.1152/ajpcell.2001.280.3.C423

328. Fehrenbach H (2001) Alveolar epithelial type II cell: defender of the alveolus revisited. Respir Res 2(1):33-46. https://doi. org/10.1186/rr36

329. Rosseau S, Selhorst J, Wiechmann K, Leissner K, Maus U, Mayer K, Grimminger F, Seeger W, Lohmeyer J (2000) Monocyte migration through the alveolar epithelial barrier: adhesion molecule mechanisms and impact of chemokines. J Immunol 164(1):427-435. https://doi.org/10.4049/jimmunol.164.1.427

330. Fortunati E, Kazemier KM, Grutters JC, Koenderman L, van den Bosch VJ (2009) Human neutrophils switch to an activated phenotype after homing to the lung irrespective of inflammatory disease. Clin Exp Immunol 155(3):559-566. https://doi.org/10.1 111/j.1365-2249.2008.03791.x

331. Bloemen PG, Van den Tweel MC, Henricks PA, Engels F, Van de Velde MJ, Blomjous FJ, Nijkamp FP (1996) Stimulation of both human bronchial epithelium and neutrophils is needed for maximal interactive adhesion. Am J Physiol 270(1 Pt 1):L80-87. https://doi.org/10.1152/ajplung.1996.270.1.L80

332. Pandya PH, Fisher AJ, Mickler EA, Temm CJ, Lipking KP, Gracon A, Rothhaar K, Sandusky GE, Murray M, Pollok K, Renbarger J, Blum JS, Lahm T, Wilkes DS (2016) Hypoxiainducible factor-1alpha regulates CD55 in airway epithelium. Am J Respir Cell Mol Biol 55(6):889-898. https://doi.org/10.1165/ remb.2015-0237OC
333. Louis NA, Hamilton KE, Kong T, Colgan SP (2005) HIFdependent induction of apical CD55 coordinates epithelial clearance of neutrophils. FASEB J 19(8):950-959. https://doi. org/10.1096/fj.04-3251com

334. Rigo I, McMahon L, Dhawan P, Christakos S, Yim S, Ryan LK, Diamond G (2012) Induction of triggering receptor expressed on myeloid cells (TREM-1) in airway epithelial cells by $1,25(\mathrm{OH})$ (2) vitamin $D(3)$. Innate Immun 18(2):250-257. https://doi. org/10.1177/1753425911399796

335. Liu F, Zhang X, Zhang B, Mao W, Liu T, Sun M, Wu Y (2018) TREM1: a positive regulator for inflammatory response via NF-kappaB pathway in A549 cells infected with Mycoplasma pneumoniae. Biomed Pharmacother 107:1466-1472. https://doi. org/10.1016/j.biopha.2018.07.176

336. Bouchon A, Dietrich J, Colonna M (2000) Cutting edge: inflammatory responses can be triggered by TREM-1, a novel receptor expressed on neutrophils and monocytes. J Immunol 164(10):4991-4995. https://doi.org/10.4049/jimmu nol.164.10.4991

337. Luissint AC, Lutz PG, Calderwood DA, Couraud PO, Bourdoulous S (2008) JAM-L-mediated leukocyte adhesion to endothelial cells is regulated in cis by alpha4beta1 integrin activation. $\mathrm{J}$ Cell Biol 183(6):1159-1173. https://doi.org/10.1083/jcb.200805061

338. Azcutia V, Kelm M, Hilgarth R, Nusrat A, Parkos CA (2019) Novel junctional adhesion molecule-like (JAML) regulates neutrophil transepithelial migration during intestinal inflammation. FASEB J 33(S1):375.377-375.377. https://doi.org/10.1096/faseb j.2019.33.1_supplement.375.7

339. Fonseca KL, Maceiras AR, Matos R, Simoes-Costa L, Sousa J, Ca B, Barros L, Fernandes AI, Mereiter S, Reis R, Gomes J, Tapia G, Rodriguez-Martinez P, Martin-Cespedes M, Vashakidze S, Gogishvili S, Nikolaishvili K, Appelberg R, Gartner F, Rodrigues PNS, Vilaplana C, Reis CA, Magalhaes A, Saraiva M (2020) Deficiency in the glycosyltransferase Gcnt1 increases susceptibility to tuberculosis through a mechanism involving neutrophils. Mucosal Immunol 13(5):836-848. https://doi.org/10.1038/ s41385-020-0277-7

340. Brazil JC, Sumagin R, Cummings RD, Louis NA, Parkos CA (2016) Targeting of neutrophil lewis X blocks transepithelial migration and increases phagocytosis and degranulation. Am J Pathol 186(2):297-311. https://doi.org/10.1016/j.ajpat h.2015.10.015

341. Brazil JC, Sumagin R, Stowell SR, Lee G, Louis NA, Cummings RD, Parkos CA (2017) Expression of Lewis-a glycans on polymorphonuclear leukocytes augments function by increasing transmigration. J Leukoc Biol 102(3):753-762. https://doi. org/10.1189/jlb.1MA0117-013R

342. Kelm M, Lehoux S, Azcutia V, Cummings RD, Nusrat A, Parkos CA, Brazil JC (2020) Regulation of neutrophil function by selective targeting of glycan epitopes expressed on the integrin CD11b/CD18. FASEB J 34(2):2326-2343. https://doi. org/10.1096/fj.201902542R

343. Colgan SP, Parkos CA, McGuirk D, Brady HR, Papayianni AA, Frendl G, Madara JL (1995) Receptors involved in carbohydrate binding modulate intestinal epithelial-neutrophil interactions. J Biol Chem 270(18):10531-10539. https://doi.org/10.1074/ jbc.270.18.10531

Publisher's Note Springer Nature remains neutral with regard to jurisdictional claims in published maps and institutional affiliations. 